\title{
Net Energy Analysis and Techno-Economic Assessment of Co-Production of Bioethanol and Biogas from Cellulosic Biomass
}

\author{
Teeraya Jarunglumlert ${ }^{1}$ and Chattip Prommuak ${ }^{2, *}$ \\ 1 Faculty of Science, Energy and Environment, Rayong Campus, King Mongkut's University of Technology \\ North Bangkok, Rayong 21120, Thailand; teeraya.j@sciee.kmutnb.ac.th \\ 2 Energy Research Institute, Chulalongkorn University, Bangkok 10330, Thailand \\ * Correspondence: chattip.p@chula.ac.th
}

\section{check for}

updates

Citation: Jarunglumlert, T.;

Prommuak, C. Net Energy Analysis and Techno-Economic Assessment of Co-Production of Bioethanol and Biogas from Cellulosic Biomass. Fermentation 2021, 7, 229. https:// doi.org/10.3390/fermentation7040229

Academic Editors:

Alexander Rapoport, John

E. Hallsworth, Justyna Ruchala and Tiffany D. Dallas

Received: 15 September 2021

Accepted: 5 October 2021

Published: 12 October 2021

Publisher's Note: MDPI stays neutral with regard to jurisdictional claims in published maps and institutional affiliations.

Copyright: (c) 2021 by the authors. Licensee MDPI, Basel, Switzerland. This article is an open access article distributed under the terms and conditions of the Creative Commons Attribution (CC BY) license (https:/ / creativecommons.org/licenses/by/ $4.0 /)$.

\begin{abstract}
Co-production is a process based on the biorefinery concept that maximizes the benefit of biomass by reusing residue from the production of one product to produce others. In this regard, biogas is one of the most researched second products for the production of ethanol from cellulosic biomass. However, operating this scheme requires additional investment in biogas processing equipment. This review compiles data from research studies on the co-production of bioethanol and biogas from lignocellulosic biomass to determine which is more worthwhile: leaving the residue or investing more to benefit from the second product. According to previous research, ethanol stillage can be converted to biogas via anaerobic digestion, increasing energy output by 2-3 fold. Techno-economic studies demonstrated that the co-production process reduces the minimum ethanol selling price to a level close to the market price of ethanol, implying the possibility of industrializing cellulosic ethanol production through this scheme.
\end{abstract}

Keywords: second-generation bioethanol; cellulosic biomass economic analysis; biorefinery; co-production; biogas

\section{Introduction}

Since the world has become aware of the severity and catastrophic consequences of global warming caused by the increase in GHG emissions, people have been paying attention and seeking ways to avert this crisis. Transportation is one of the sectors with the highest GHG emissions [1] and is thus a priority for researchers to focus on. In this regard, although electric vehicles (EV) are seen as a promising option to reduce GHG emissions in the transport sector, it is undeniable that charging an EV battery requires large electricity consumption, conversely causing GHG emissions. As a result, rather than relying on a single option, it is critical to diversify strategies for reducing GHG emissions in the transportation sector [2].

Biofuel is a type of fuel obtained from biomass, or organic matter derived from plants and animals by photosynthesis. These also include agricultural and organic fractions of municipal waste [3]. Therefore, biofuel is not only a low-carbon alternative to fossil fuels but is also an important component in promoting a circular bioeconomy [4]. Available in a variety of forms, biofuels may be gases, e.g., biomethane and biohydrogen, solids (biomass), and liquids, e.g., vegetable oil, biodiesel, and bioethanol. For more than two decades, the latter two liquid biofuels have been promising alternatives to fossil fuels for vehicle propulsion [5]. In particular, bioethanol has been proven to emit 39-43\% fewer GHGs than gasoline and could potentially be up to $47-70 \%$ lower with developed technologies [6]. To date, the majority of gasoline-powered automobiles already run on a blend of ethanol and gasoline, with a minimum of $5 \%$ ethanol by volume up to $85 \%$, referred to as E5 and E85, respectively [7]. 
Today, the majority of commercially produced bioethanol is derived from first-generation (1G) feedstock, including sugar-based materials, especially sugarcane, and starch-based biomass such as corn, cassava, and wheat. Therefore, as the demand for these fuels rises, the scramble for agricultural raw resources for fuel production is anticipated as a possible contribution to an increase in food prices [8]. Biomass waste from field crops and agriculture, such as bagasse, cassava rhizomes, empty fruit bunches, rice straw, and so on, is a lignocellulosic biomass that also has the potential to produce bioethanol. It is thus regarded as a feedstock for the production of second-generation (2G) biofuels. Primarily, lignocellulosic biomass contains cellulose, hemicellulose, and lignin in different proportions according to the diversity of biomass species [9]. To produce bioethanol from lignocellulosic biomass, it is necessary that the biomass is first pretreated to remove the lignin and other unwanted portions. The resulting cellulose and hemicellulose are then hydrolyzed to produce reducing sugars, including hexose (C6 sugars), which is mostly glucose, and pentose (C5 sugars) such as xylose and arabinose. Subsequently, these sugars are then fermented in the same manner as the $1 \mathrm{G}$ biomass. Besides bioethanol, biogas is another interesting alternative energy. Through anaerobic digestion (AD), organic matter is converted to biogas through microbial activity $[10,11]$. Comprising approximately $60 \%$ methane and $40 \%$ carbon dioxide, the produced biogas is a fuel that may be utilized for heating, power generation, and automobile fuel.

The process of breaking down waste cellulosic biomass into smaller units so that each unit can be a feedstock to re-create many more products is based on the concept of the biorefinery. With this approach, waste biomass may be managed in such a way that economic and environmental benefits are optimized. Biorefineries are therefore viewed as a viable option to help manage waste efficiently, and they are gaining interest worldwide. With several pathways, the biorefinery has the potential to create a sustainable value chain from multiple products, including biofuel and bioenergy; fibers; chemicals; and building blocks or precursors for fine chemicals, bioplastics, food and feed, and biopharmaceuticals [12]. Adopting the biorefinery concept, co-production of bioethanol and biogas is an interesting strategy to improve the economics of the production of either ethanol or biogas alone. During enzymatic hydrolysis, the monomers of hexose and pentose sugars in the carbohydrate polymers are liberated. However, there are currently no fermenting microorganisms capable of effectively producing ethanol from pentose sugars. The residual stillage from ethanol production thus retains pentose, which can be used as a feedstock for further biogas production via AD [13]. Moreover, a final solid residue obtained from such a scheme was modified to be better suited as a salable soil conditioner, thereby increasing revenue. Thus, this approach is recognized as a promising process for effective waste management that improves the economics of the ethanol plant by making use of most of the biomass, as in the biorefinery concept.

Considering all the above noteworthiness, there have been numerous studies on the co-production of bioethanol and biogas from lignocellulosic biomass over the last decade. The question is, even if the co-production does top up revenue, will the resulting increase in process complexity, additional equipment, and extra energy required to produce this supplemental product still make this scheme economically viable? Attempting to discover answers to this question, there are several research studies on net energy analysis and techno-economic assessment of the co-production. However, they are difficult to compare due to a distinct set of power units and assumptions given in each study. This review compiles data from research studies on $2 \mathrm{G}$ biofuel co-production, including the uniqueness and outstanding characteristics of each pretreatment, which is an important step that determines the efficiency of bioethanol production. Due to the variety of ways to process the co-production, this review categorized the co-production schemes into three groups and recalculated the output obtained from each study on the same basses. Herein, the energy outputs are all presented in GJ/ton biomass and in gasoline/liter equivalent, allowing for discussion and comparison of each study. In addition, the energy efficiency indicators and key assumptions used in the studies on techno-economic assessment, which 
differ in calculations and definitions, are also included. Finally, in order to visualize the practical feasibility, the authors presented minimum ethanol selling prices (MESPs) from each research study on the co-production in comparison to the ethanol market price.

\section{First-Generation Bioethanol}

Bioethanol is typically produced by fermenting C6 sugars (mostly glucose) with conventional or genetically modified yeasts such as Saccharomyces cerevisiae. Under anaerobic conditions, the yeast consumes glucose and converts it to ethanol through glycolysis [14]. Eventually, to recover and purify the ethanol obtained from the fermentation broth, distillation and dehydration are carried out. In theory, as the exothermic reaction takes place, 1 mole of glucose is transformed into 2 moles of ethanol and 2 moles of carbon dioxide. Therefore, this basically implies that any type of raw material containing glucose can be used to ferment ethanol. $1 \mathrm{G}$ bioethanol is directly tied to edible biomass, including sucrosecontaining feedstock such as sugarcane and sugar beet, and starchy biomass, primarily corn, cassava, wheat, etc. Using sugarcane to produce bioethanol, as in Brazil, Argentina, India, and Thailand, sugarcane juice as well as byproducts of sugar production, such as molasses, are fermentation substrates [15]. In such a case, after some simple preparation, the feedstock can be directly subjected to fermentation. In many of the world's major ethanol producers, such as the USA, China, the UK, and Canada, a great deal of starch-based biomass is used to produce ethanol [15]. Nevertheless, due to the yeast's inability to directly ingest large molecule carbohydrates, these starches must first be broken into smaller sugars via hydrolysis prior to fermentation; enzymatic hydrolysis is mostly implemented rather than acid hydrolysis due to its favorable efficiency [16].

The conditions for optimal hydrolytic enzyme activity differ significantly from those for fermenting yeast function. In particular, celluloses usually give the highest hydrolysis yield when operated at around $50{ }^{\circ} \mathrm{C}$ or above, while the optimal temperatures for $S$. cerevisiae to produce ethanol are in the lower range of no more than $40^{\circ} \mathrm{C}$ [17]. Originally, the two steps in ethanol production are carried out in a separate unit, known as separate hydrolysis and fermentation (SHF), to ensure that those suitable conditions are given. Additionally, this scheme promotes mass transfer and eases post-fermentation yeast recycling. However, with SHF, the cellulases are end product-inhibited, meaning their productivity drops as sugar concentration increases [18]. In addition to that, inhibitors in the processed biomass slurry, such as sucrose and lignin breakdown products, may also inhibit enzyme activity $[19,20]$. To compensate for the reduced rate of enzymatic reaction, the hydrolysis reactor in SHF is usually built large enough to serve the unavoidably extended retention time and thus results in an extra capital cost [17].

To address the limitations of SHF, simultaneous saccharification and fermentation (SSF) was later developed. With SSF, cellulose and fermenting yeast are added all at once, allowing simultaneous enzymatic hydrolysis and ethanol fermentation to keep glucose concentration at a low level, thus reducing the risk of inhibition found in SHF. Therefore, SSF may require a lower amount of enzyme compared to SHF [21]. Furthermore, because SSF requires less energy to run two processes in a single reactor, not only the investment cost but also the operating expenses are lessened [22].

\section{Second-Generation Bioethanol}

$2 \mathrm{G}$ bioethanol was developed to address the limitations of $1 \mathrm{G}$ bioethanol, which was criticized for competing with food production for water and arable land, potentially leading to food price increases [23]. 2G bioethanol is derived from non-edible cellulosic biomass, including: (1) homogeneous biomass (e.g., wood chips), (2) quasi-homogeneous biomass (e.g., forest and agricultural residues), and (3) non-homogeneous biomass (municipal solid waste, organic fraction, in particular) $[16,24]$. This lignocellulosic biomass is primarily composed of two types of carbohydrate polymers, i.e., cellulose and hemicellulose, and a non-carbohydrate phenolic polymer called lignin. Each biomass has unique characteristics based on the proportions of these three components. Typically, herbaceous plants comprise 
$25-95 \%$ cellulose, $20-50 \%$ hemicellulose, and 0-40\% lignin. Softwood contains $33-42 \%$ cellulose, $22-40 \%$ hemicellulose, and $21-32 \%$ lignin, whereas hardwood contains $38-51 \%$ cellulose, $17-38 \%$ hemicellulose, and $21-31 \%$ lignin [25].

Cellulose is a crystalline and amorphous polymer of 7000-15,000 molecules of Dglucose linked by glycosidic bonds, while hemicellulose is a shorter chain of polysaccharides consisting of 500-3000 sugar units such as pentose and xylose. Therefore, cellulose is a priority for the source portion of bioethanol production, followed by hemicellulose, while lignin only plays a negative role in this regard [26]. According to the robust structure of cellulosic biomass, which causes recalcitrance to enzymatic digestion, it is necessary that biomass be additionally pretreated prior to hydrolysis.

\subsection{Biomass Pretreatment}

Pretreatment is the crucial stage in achieving feasible $2 \mathrm{G}$ bioethanol production. Efficient pretreatment must decompose lignin, liberating cellulose and hemicellulose, making enzymes accessible for digesting them into as many small sugar molecules as possible. Moreover, pretreatment must be carried out in conditions that prevent polysaccharide from undergoing degradation while also being highly selective in order to limit the formation of inhibitors $[27,28]$. Whether biologically, chemically, physically, or physicochemically, pretreatments affect one or more of the following properties at once: crystallinity of cellulose, degree of cellulose, polymerization, accessible surface area, lignin and hemicellulose shield, hemicellulose acetylation, etc. [29].

Physical pretreatments are typically used to lower the particle size of biomass in order to enhance the surface area and facilitate enzymatic accessibility in the subsequent hydrolysis [28]. This is commonly accomplished through the use of mechanical equipment such as millers, grinders, and screws, or more sophisticated techniques such as ultrasound and ultraviolet or microwave radiation, which is frequently found to aid in chemical conditions, referred to as physicochemical pretreatment. Physical pretreatment can also be accomplished via thermomechanical methods, such as steam explosion (SE) or liquid hot water (LHW). Although the processes both utilize water at around $160-260^{\circ} \mathrm{C}$ as the biomass breakdown medium, they are governed by different mechanisms. In SE, biomass is exposed by steam at a pressure of approximately 7-50 bar [30]. After a few minutes, the vessel is abruptly depressurized, resulting in the breakdown of the cell structure due to expansion of steam, similar to an explosive action. On the other hand, employing hot water at the pressure at which it remains in the liquid state, LHW, is more akin to acid hydrolysis and is thus classified as a chemical pretreatment in some literatures [31]. This is because the destruction of biomass during LHW is dependent on the hydronium ions created during the water auto-ionization at such elevated temperatures. These ions cause acetyl groups in hemicelluloses to form acetic acid, which plays a vital role in biomass breakdown.

Chemical pretreatment has emerged as one of the most promising ways for enhancing cellulose's biodegradability. Pretreated biomass exhibits a range of qualities depending on the chemical used. Using acid, most commonly, $\mathrm{H}_{2} \mathrm{SO}_{4}, \mathrm{HCl}$, and $\mathrm{H}_{3} \mathrm{PO}_{4}$, is very successful at breaking glycosidic bonds, causing damage to the lignocellulose matrix, which results in polysaccharide conversion to oligomers and monomers. Not only does this approach primarily affect hemicellulose, it also partially dissolves lignin and cellulose, releasing oligomers accordingly [32]. However, the process's main disadvantage is the presence of a variety of inhibitory chemicals created by sugar degradation and lignin decomposition, such as aldehydes, phenolic acids, and ketones [33].

When alkali, such as $\mathrm{NaOH}$ and $\mathrm{Ca}(\mathrm{OH})_{2}$, is used in the pretreatment process, it breaks the ester bond between lignin and hemicellulose and disrupts the lignin structure's ether bond. This results in the breakdown of some hemicellulose and lignin into smaller molecules that can be dissolved in alkaline solution. Cellulose, on the other hand, remains the primary element of undiluted lignocellulose. Additionally, the alkaline solution causes the lignocellulose structure to swell, increasing the interior surface area [34]. Apart from aqueous hydroxide base solutions, ammonia fiber explosion (AFEX) is another alkaline 
pretreatment that involves treating moist biomass with anhydrous ammonia at moderate temperatures $\left(70-200^{\circ} \mathrm{C}\right.$ ) and pressures (100-400 psi) [35], followed by a rapid release of pressure to rapture cell structure via explosive action, similar to the above steam explosion.

The organosolv method is another chemical pretreatment that involves the use of organic solvents such as ethanol, methanol, acetone, and ethylene glycol, or a combination of these solvents and water. Alternatively, in some studies, the treatment was catalyzed by the addition of acids or bases [36]. This technique is capable of removing lignin and hydrolyzing hemicellulose. After pretreatment of the biomass with the solvent, two phases form: the black liquor phase, which contains the majority of the dissolved lignin, and the remaining solids phase [37]. The disadvantage of this method of pretreatment is that the solvent must be completely removed before the pretreated biomass is processed in the following step, as these organic solvents possess inhibitory effects on fermentation.

Ionic liquid (IL) and supercritical fluid (SCF) are two chemical pretreatment methods that are recognized as green technologies due to their environmentally friendly characteristics. Typically, ILs are made up of large organic cations and small organic or inorganic ions. The unique feature of ILs is that their properties and functionality can be customized by modifying those ions. For example, 1-butyl-3-methylimidazollium chloride was found to easily dissolve microcrystalline cellulose [38], and 1-ethyl-3-methylimidazollium acetate was found to be highly effective at delignification [39]. Nevertheless, despite many technical advantages over other pretreatment technologies, IL pretreatment possesses economic difficulties [40]. The supercritical fluids (SCFs) commonly used in biomass pretreatment are supercritical carbon dioxide $\left(\mathrm{SCCO}_{2}\right)$ and supercritical water $(\mathrm{SCW})$. At a supercritical state, the behavior of these relatively inexpensive, non-toxic solvents is in-between that of liquids and gases. As a result, they exhibit unique physicochemical properties such as high diffusion and low viscosity, which allow rapid mass transfer through biomass [37].

In pretreatment by biological processes, the degradation of lignin and hemicellulose from lignocellulosic biomass is governed by the activity of microorganisms that secrete ligninolytic enzymes, or by the enzymes directly. For this purpose, brown, white, and soft rot fungi are frequently studied [41]. Being operated in mild conditions, the fact that there are no toxic byproducts that inhibit subsequent hydrolysis is the well-known advantage of this technique. However, the biological process has the disadvantage of taking an extended period of time to degrade biomass. Furthermore, because all processes must be carried out under sterile conditions, biological pretreatment on a large scale is very costly [42].

With the different characteristics of each pretreatment, it is not possible to ascertain which method is best for all forms of biomass due to their structural and compositional differences. Therefore, each pretreatment method has unique benefits and drawbacks when applied to different types of biomass. Figure 1 summarizes the specific characteristics of each technique, highlighting the benefits and drawbacks to varying degrees. (Data modified from de Lima et al. (2016) [29] and Patel and Shah (2021) [43]).

\subsection{Current Stage of Second-Generation Bioethanol}

\subsubsection{Bottlenecks in Second-Generation Bioethanol}

What complicates the production of ethanol from cellulosic biomass is that the glucose in this type of biomass is not in a ready-to-ferment form as in the $1 \mathrm{G}$ biomass. After cellulosic biomass undergoes pretreatment, glucose is liberated along with many other hydrolysates, some of which strongly inhibit the kinetics of the subsequent enzymatic hydrolysis or fermentation $[33,44]$. The variation of these inhibitors is dependent on the chemical pathway of the pretreatment to which the biomass is subjected. For instance, pretreated in acid solution under elevated temperature, acetylic acid is produced as the acetyl groups in hemicellulose are hydrolyzed, while furfural and 5-hydroxymethylfurfural (5-HMF) are formed as a result of dehydration of pentoses and hexoses [44]. None of these inhibitors are found in the hydrolysates of alkaline pretreatment. Instead, coumaric acid, formic acid, and acetic acid are presented [45]. 

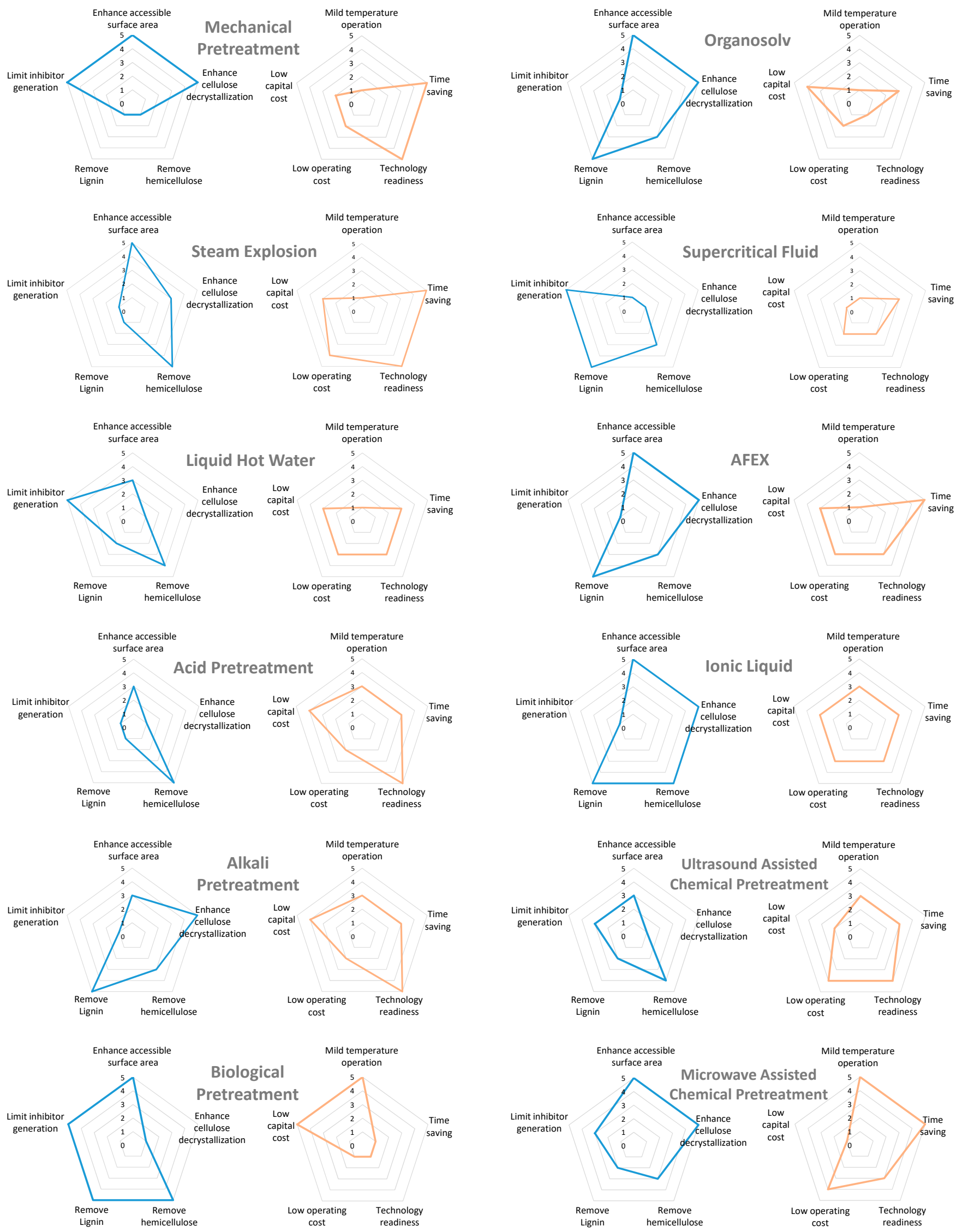

Figure 1. Radar chart of the characteristic effect on biomass (blue) and additional benefits (orange) of pretreatment method. 
Low-cost pretreatments, such as those involving the use of acid, alkali, and organic solvents, tend to produce a large amount of inhibitors, while those that effectively limit inhibitor formation, such as steam explosions and biological techniques, are expensive in operation [29]. Using a low-cost pretreatment may thus necessitate the addition of a unit to detoxify or remove those inhibitors, thereby conversely increasing production costs. However, separation of the inhibitors, on the other hand, enables them to be valorized into high-value products. Without the separation or detoxification after biomass pretreatment, these inhibitors could considerably lower yeast metabolic rates, resulting in a significant fall in ethanol conversion efficiency [46]. Increasing the ethanol yield in the other direction, the inhibitors must be kept to a minimum using more specific techniques.

\subsubsection{Commercial Production of Second-Generation Bioethanol}

Commercial-scale ethanol production from cellulosic biomass has actually existed for a long period of time. Borregaard (Sarpsborg, Norway) and Domsjö Fabriker AB (Domsjö, Sweden) began producing cellulosic ethanol, lignin, and a variety of other products in 1938 and 1940, respectively, in addition to their primary product, wood-derived cellulose. Although the ethanol was produced as a byproduct, its capacity is considered to be on a commercial scale (20 and 22 million tons per year (MLPY), respectively) [47].

By the end of 2012, Beta Renewables officially opened an industrial plant producing cellulosic ethanol in Crescentino, Italy. Using agricultural waste, i.e., wheat and rice straw, and energy crops, i.e., Arundo donax and miscanthus, Beta Renewables is the first plant in the world that produces $2 \mathrm{G}$ bioethanol as a main product, with a capacity of 50 MLPY [48]. That same year, China began producing $2 \mathrm{G}$ commercial scale ethanol as the first country in Asia. Longlive Group (Yucheng, Shandong), followed by Tianguan Group (Nanyang, Henan) a year later, started up the plants with capacities of 63 MLPY using corn cob and 38 MLPY using corn and wheat stalks, respectively [49]. Later in 2016, India became the second country in Asia to produce 2G bioethanol on a commercial scale. Located in Bathinda, Punjab, a 32 MLPY cellulosic bioethanol plant was established by Hindustan Petroleum Corporation Limited and the Institute of Chemical Technology using agricultural as a feedstock [50].

From 2014 to 2019, many countries in the Americas had established several 2G ethanol plants. Most plants located in the US use agricultural waste such as corn stover and wheat straw with varying capacities, i.e., 30 MLPY by INEOS Bio (Vero Beach, FL, USA) [51], 76 MLPY by POET-DSM Advanced Biofuels (Emmetsburg, IO, USA), 95 MLPY by Abengoa Bioenergy (Hugoton, KS, USA), 114 MLPY by DuPont (Nevada, IO, USA) [52]. Moreover, there are two companies using different feedstocks, including municipal solid waste by Fiberight (Hampden, ME, USA) and dedicated energy crops by Beta Renewables, (Clinton, NC, USA) with production capacities of 23 MLPY [53] and 75 MLPY [54], respectively. As the world's second largest sugarcane growing country, the production of cellulosic ethanol with a capacity of 82 MLPY by GranBio (São Miguel dos Campos, Alagoas) [54] and 40 MLPY by Raízen and Iogen (Piracicaba, São Paulo) in Brazil, both use sugarcane straw and bagasse as feedstocks [55]. Unlike the others, two plants located in Canada by the same manufacturer, Enerkem, use municipal waste to produce bioethanol, both with equal production capacities of 38 MLPY [56].

Since 2017, Europe has resumed its investment in 2G bioethanol production. Most of which still use woody biomass (forest industry residues) as feedstock. There are also two other plants that use agricultural waste, as described below [54]:

- 10 MLPY by St1 and SOK (NEB) (Kajaani, Finland), started in 2017, using sawdust as feedstock

- 70 MLPY by Energochemica and Beta Renewables (Strazske, Slovakia), started in 2018, using agricultural waste (wheat straw, rapeseed straw, corn stover) and dedicated energy crops (switchgrass) as feedstock

- 63 MLPY by Clariant (Southwestern part of Romania), started in 2020, using agricultural waste (wheat straw and other cereals) as feedstock 
- 50 MLPY by St1, SOK and NEOT (Pietarsaari, Finland), started in 2020, using forest industry residues as feedstock

- 50 MLPY by St1 and Vikeng Skog SA (Hønefoss, Norway), starting in 2021, using forest industry residues as feedstock

It should be noted that most plants do not produce bioethanol alone, but also coproduce other byproducts. Typically, using wood as a feedstock, cellulose and lignin, as well as lignin-derived products such as biovanillin, are co-produced [47]. Plants that produce $2 \mathrm{G}$ bioethanol based on agricultural residue often co-produce a variety of high-value alcohols and biochemicals such as xylitol, n-butanol, butanediol, succinic acid, etc. [43]. Another common co-product associated with the production of $2 \mathrm{G}$ bioethanol, regardless of the feedstock used, is other biofuels and grid-supplied electricity. However, many $2 \mathrm{G}$ bioethanol companies had struggled to stay afloat and later closed down their businesses, while there are still many others currently on plans to establish cellulosic bioethanol production plants in the near future $[49,54]$.

\section{Co-Production of Second-Generation Bioethanol and Biogas}

Adopting the concept of the biorefinery entails the use of all parts of the raw material to the maximum benefit. Residual cellulosic biomass is the main target raw material for research and development based on the concept of the biorefinery due to its abundant availability. The biorefinery process produces a diverse range of products, ranging from high volume/low value to high value/low volume: biofuel and bioenergy, fibers, chemicals, as well as building blocks or precursors for fine chemicals, bioplastics, food and feed, and biopharmaceuticals $[57,58]$. The term "high value", as previously stated, relates to a complicated manufacturing process that results in high production costs. As producing biofuels is not as complex as producing high-value products, many studies have been conducted to determine the feasibility of producing $2 \mathrm{G}$ bioethanol in combination with other biofuels, especially biogas, in order to pursue the biorefinery concept.

Biogas is widely disseminated in many industrialized agricultural countries. This type of gaseous biofuel is naturally produced when organic material degrades in the absence of oxygen, known as anaerobic digestion (AD). During AD, organic matter undergoes four stages, including hydrolysis, acidogenesis, acetogenesis, and methanogenesis [59]. Each phase involves distinct groups of bacteria that are partially syntrophic with one another and have distinctive requirements of the environment. Hydrolysis takes place as hydrolytic bacteria release exoenzymes such as alymase, proteiase, lipase, etc., to break down complex compounds into smaller forms. As a result, many monomers, such as fatty acids, monosacaride, aminopurine, pyrimidine, etc., are presented. Being consumed by acid-forming bacteria, the hydrolyzed compounds undergo the acidogenesis phase, producing volatile fatty acids (VFAs), including alcohol and long-chain fatty acids, as by-products of their growth. During the acetogenesis stage, acetogeneic bacteria convert these VFAs to simpler compounds such as acetic acid, hydrogen, and carbon dioxide, which are eventually converted to methane by another group of microorganisms called methanogens. Due to the fact that bioethanol and biogas share a common raw material, a large number of studies on combining the two processes for sequential production of bioethanol and biogas have been identified, as summarized in Table 1. 
Table 1. Summary of studies on co-production of bioethanol and biogas from cellulosic biomass.

\begin{tabular}{|c|c|c|c|}
\hline Ref. & Feedstock & Process Scheme & Pretreatment \\
\hline [60] & $\begin{array}{l}\text { Napier } \\
\text { grass }\end{array}$ & $\begin{array}{c}\mathrm{SC} 1: \mathrm{PT} \rightarrow \mathrm{DSSF} \\
\text { SC2: } \mathrm{PT} \rightarrow \mathrm{AD} \\
\mathrm{SC} 3: \mathrm{PT} \rightarrow \mathrm{DSSF} \rightarrow \mathrm{AD}\end{array}$ & $\begin{array}{l}\text { Ensiling } \\
\text { - } \quad \text { Conducted in a vacuumed and } \\
\text { sealed plastic silo bag and then } \\
\text { stored at ambient temperature } \\
\text { for } 90 \text { days } \\
\text { Alkaline pretreatment } \\
\text { - } \quad \text { Alkaline solution: } 2 \% \mathrm{NaOH} \\
\quad(w / v) \\
\text { - } \quad \text { Solid to liquid: } 1 \text { to } 20(w / v) \\
\text { - } \quad \text { Temperature: } 80^{\circ} \mathrm{C} \\
\text { - } \\
\text { Retention time: } 2 \mathrm{~h}\end{array}$ \\
\hline
\end{tabular}

[61] $\begin{gathered}\text { Raw seaweeds, } \\ \text { Cu-sorbed } \\ \text { seaweeds }\end{gathered} \quad \mathrm{AHD} \rightarrow \mathrm{PT} \rightarrow \mathrm{FM} \rightarrow \mathrm{AD}$

Acid hydrolysis using $2 \mathrm{~N} \mathrm{H}_{2} \mathrm{SO}_{4}(1 \%$ $w / v)$, followed by thermal treatment with hot steam in autoclave at $120^{\circ} \mathrm{C}$ for $60 \mathrm{~min}$

[62]

Organic fraction of municipal waste (OFMW)
$\mathrm{PT} \rightarrow \mathrm{DSSF} \rightarrow \mathrm{DL} \rightarrow \mathrm{AD}$

PT $\rightarrow$ DSS $\rightarrow$ DL $\rightarrow$ AD
Mechanical pretreatment

Highlight/Finding

- Without pretreatment, the coproduction yielded $65.2 \mathrm{~g}$ of ethanol and $102.6 \mathrm{~g}$ of methane from $1 \mathrm{~kg}$ of biomass.

- Of all the pretreatments applied in the study, Ensiling- $\mathrm{NaOH}$ provided the highest production of ethanol and methane, yielding $269.4 \mathrm{~g}$ and $144.5 \mathrm{~g}$ from $1 \mathrm{~kg}$ of biomass, respectively.

- $\quad$ Energy recovery from coproduction was $98.9 \%$ higher than that from ethanol production alone and $53.6 \%$ higher than that from AD only.

- $\quad$ Fermentation alone, heavy metals resulted in lower bioethanol yield due to the unfavorable impact on the yeast activity.

- In the co-production of bioethanol and methane, fermentation reduced the negative impact of the metal ion on $\mathrm{AD}$, resulting in a greater methane yield from fermented $\mathrm{Cu}$-sorbed seaweed than the fermented seaweed.

- Compared with production of methane alone, the sequential production of ethanol and methane from the $\mathrm{Cu}$-sorbed seaweeds provided the $93 \%$ higher gross energy output.

- $\quad$ Source-sorted OFMW as feedstock for DSSF provided up to $80 \%$ yield of ethanol, while the maximum ethanol yield obtained from non-sorted-OFMW was $59 \%$.

- Subsequent introduction of stillage from the ethanol production to $\mathrm{AD}$ yielded $384.6 \mathrm{~mL} / \mathrm{g}$ VS. methane, which is slightly higher than that obtained from source-sorted-OFMW (380.9 mL/g VS) that had undergone only mechanical pretreatment.

- The highest ethanol yield (10.3 g/L) was obtained from the trial where biomass was pre-treated at $170^{\circ} \mathrm{C}$.

Nitrogen explosive decompression (NED)

SC1: AD

SC2: $\mathrm{PT} \rightarrow \mathrm{AD}$

[63] Napier
grass SC3: $\mathrm{PT} \rightarrow \mathrm{EHD} \rightarrow \mathrm{AD}$ SC4: $\mathrm{PT} \rightarrow \mathrm{SHF} \rightarrow \mathrm{DL} \rightarrow \mathrm{AD}$

- $\quad$ Vessel: 2 L non-stirred pressure vessel

- $\quad$ biomass to distilled water: 100 to $800(\mathrm{~g} / \mathrm{g})$

- $\quad$ Temperature: 150, 170, 190, 200 ${ }^{\circ} \mathrm{C}$

- $\quad$ Pressure: 30 bar

- Retention time: $1 \mathrm{~min}$
- Methane yields are higher in samples pretreated at lower temperatures. The maximum methane yields were obtained from the solid fraction of post-pretreatment broth at $150{ }^{\circ} \mathrm{C}(1.13$ mol CH $4 / 100 \mathrm{~g}$ ).

- $\quad$ The liquid fraction after the pretreatment stage should be separated and discarded from the bioethanol production process because it contains inhibitory compounds and does not add value to the production chain.

- $\quad$ EtOH production waste can be used for further $\mathrm{AD}$ to add value to the bioethanol production chain.

- Methane obtained from the fermented BS was highest $\left(1.21 \mathrm{~mol} \mathrm{CH}_{4} / 100 \mathrm{~g}\right.$ biomass), followed by that from ethanol production waste $\left(1.17 \mathrm{~mol} \mathrm{CH}_{4} / 100 \mathrm{~g}\right.$ biomass), hydrolyzed BS (1.13 mol $\mathrm{CH}_{4} / 100 \mathrm{~g}$ biomass), pretreated BS (1.11 $\mathrm{mol} \mathrm{CH}_{4} / 100 \mathrm{~g}$ biomass), and raw BS (1.04 $\mathrm{mol} \mathrm{CH}_{4} / 100 \mathrm{~g}$ biomass). 
Table 1. Cont.

\begin{tabular}{|c|c|c|c|c|}
\hline Ref. & Feedstock & Process Scheme & Pretreatment & Highlight/Finding \\
\hline [65] & $\begin{array}{l}\text { Artificial food } \\
\text { waste (AFW) }\end{array}$ & $\mathrm{DSSF} \rightarrow \mathrm{AD}$ & None & $\begin{array}{l}\text { Although the amount of biogas obtained from } \\
\text { the fermented AFW ( } 680 \mathrm{~mL} / \mathrm{g} \text { VS) was lower } \\
\text { than that from the non-fermented AFW ( } 800 \\
\mathrm{~mL} / \mathrm{g} \text { VS), it contains a higher percentage of } \\
\text { methane }(67.5 \mathrm{vs} .53 .1 \% \text { ) and result in an } \\
\text { overall methane yield of } 460 \mathrm{vs} .420 \mathrm{~mL} / \mathrm{g} \text { VS. }\end{array}$ \\
\hline [66] & $\begin{array}{l}\text { Barley } \\
\text { straw }\end{array}$ & $\mathrm{PT} \rightarrow \mathrm{DSSF} \rightarrow \mathrm{DL} \rightarrow \mathrm{AD}$ & $\begin{array}{l}\text { - Nitrogen explosive } \\
\text { decompression (NED) } \\
\text { Synthetic flue gas }\left(20 \% \mathrm{CO}_{2} \text { and }\right. \\
\left.80 \% \mathrm{~N}_{2}\right) \text { explosive } \\
\text { decompression }\end{array}$ & $\begin{array}{l}\text { Pretreated by NED, the methane was } \\
8-12 \% \text { greater in yield than that which } \\
\text { had undergone pretreatment with flue } \\
\text { gas. } \\
\text { The greatest methane yields were } \\
\text { obtained from fermentation and } \\
\text { distillation sidestreams }(0.53 \text { and } 0.58 \mathrm{~mol} \\
\mathrm{CH}_{4} / 100 \mathrm{~g} \text {, respectively). } \\
\text { The liquid fractions yielded a } 60-88 \% \\
\text { lower amount of methane than the solid } \\
\text { fractions. }\end{array}$ \\
\hline
\end{tabular}

Alkaline thermal hydrolysis

- $\quad$ Biomass to solution: 1 to 1.25

- $\mathrm{Ca}(\mathrm{OH})_{2}$ solution: $5 \mathrm{~g} \mathrm{Ca}(\mathrm{OH})_{2}+$ $130 \mathrm{~mL}$ of distilled $\mathrm{H}_{2} \mathrm{O}$ )

- Pressure: $0.15 \mathrm{MPa}$

- Temperature: $135^{\circ} \mathrm{C}$

- Retention time: $30 \mathrm{~min}$

Hydrothermal pretreatment

- Water to biomass: 10 to 1

- Temperature: $121{ }^{\circ} \mathrm{C}$ (autoclave)

- Retention time: $15 \mathrm{~min}$

$\mathrm{SC} 1: \mathrm{PT}_{1} \rightarrow \mathrm{AD} \rightarrow \mathrm{SHF}$

[68] Aquatic weeds

$\mathrm{SC} 2: \mathrm{PT}_{2} \rightarrow \mathrm{AD} \rightarrow \mathrm{SHF}$

Thermochemical treatment

SC3: $\mathrm{PT}_{1} \rightarrow \mathrm{SHF} \rightarrow \mathrm{AD}$

SC4: $\mathrm{PT}_{2} \rightarrow \mathrm{SHF} \rightarrow \mathrm{AD}$

- Acid solution: $1 \% \mathrm{H}_{2} \mathrm{SO}_{4}$

- Biomass loading: $6 \%(w / v)$

- Temperature: $121{ }^{\circ} \mathrm{C}$

- Retention time: $15 \mathrm{~min}$

Alkaline pretreatment

- Alkaine solution: $\mathrm{NaOH}(0.5$ $\mathrm{mol} / \mathrm{L}$ )

Note:

[69]

SCB = Sugarcane bagasse

DER = Starch-rich waste of Dioscorea

composita Hemls. extracted residue
- $\quad$ Solid to liquid ratio: 1 to $20(w / v)$

- Temperature: $80^{\circ} \mathrm{C}$

- $\quad$ Retention time: $2 \mathrm{~h}$

- Note: SCB = Sugarcane bagasse DER $=$ Starch-rich waste of Dioscorea composita Hemls. extracted residue
The ethanol stillage contains biodegradable components that can be consumed by methane bacteria. This probably results in an acceleration in the acid phase and effective methanogenesis progression.

- Total energy from highest to lowest: SC1 $>$ SC4 > SC2 > SC3 (for all seaweed species).

- $\quad$ The order in which sequential biofuel production, whether AD or FM, should be conducted is dependent on the pre-treatments.

- Hydrothermal pretreatment makes the biomass more suitable for performing AD first, while thermochemical pretreatment makes the biomass more suitable for performing FM first.

- $\quad$ The optimal mixture ratio of DER:SCB:molasses was 1:0.5:0.5.

- The highest theoretical yield of ethanol $(69 \%)$ was obtained with fed-batch+Tween 80 mode SSF at a solids loading of $44 \%$.

- $\quad$ The addition of biomethane, $320.7 \mathrm{~mL} / \mathrm{g}$ VS, was obtained as the fermentation stillage was directed further to AD.

Stream explosion

- Temperature: $195^{\circ} \mathrm{C}$

- $\quad$ Pressure: 1.6 MPa

[70] $\begin{gathered}\text { Napier } \\ \text { grass }\end{gathered}$

SC1: PT $\rightarrow$ AD SC3: $\mathrm{PT} \rightarrow \mathrm{DSSF} \rightarrow \mathrm{DL} \rightarrow \mathrm{AD}$

- $\quad$ Retention time: $5 \mathrm{~min}$

Alkali pretreatment

- Alkaline solution: $\mathrm{NaOH}$ solution $(2 \%, v / v)$

- Biomass to solution ratio: $10 \%$ $(w / v)$

[71] Rice

C1: PT $\rightarrow$ AD $\mathrm{PT} \rightarrow \mathrm{SHF} \rightarrow \mathrm{DL} \rightarrow \mathrm{AD}$ $\mathrm{SC} 3: \mathrm{PT} \rightarrow \mathrm{SHF} \rightarrow \mathrm{AD}$
- Retention time: $48 \mathrm{~h}$

- Temperature: $60^{\circ} \mathrm{C}$
From $1 \mathrm{~kg}$ of dry grass:

- $\quad$ SC1: produces $66.4 \mathrm{~g}$ methane (3.4 MJ).

- SC2: produces $121.6 \mathrm{~g}$ ethanol (3.6 MJ).

- $\quad$ SC3: produces $121.6 \mathrm{~g}$ ethanol and $110.6 \mathrm{~g}$ methane $(9.3 \mathrm{MJ})$

- $\quad$ Energy outputs from high to low: SC3 (biomethane only) > SC2 (bioethanol + biomethane) > SC1 (biomethane only).

- The highest yield of biomethane, obtained in SC3, was due to the free xylose and the remaining ethanol in the fermentation broth, which promoted methanation. 
Table 1. Cont.

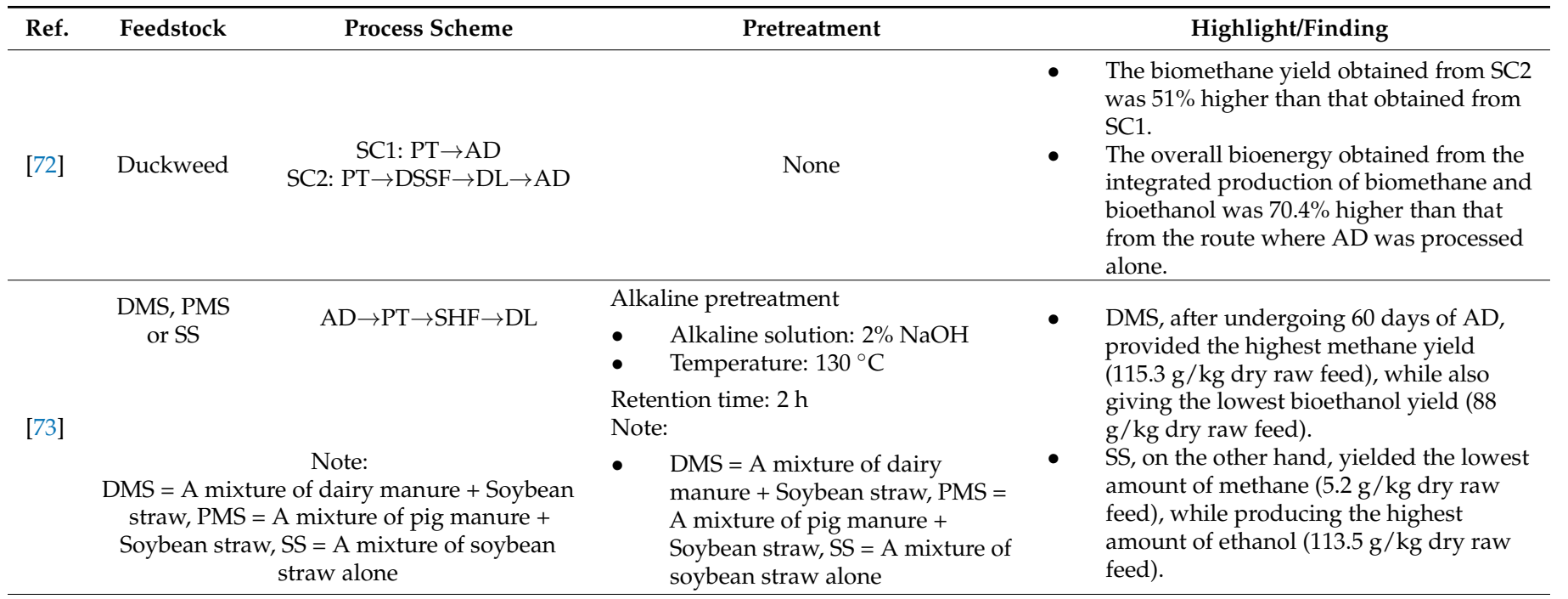

Steam explosion

- Reactor volume: $12 \mathrm{~L}$

- $\quad$ Liquid to solid ratio: 2

- Acid catalyst: $0,0.2,2 \mathrm{wt} \%$ of biomass

- Retention time: $10 \mathrm{~min}$

[74] $\begin{gathered}\text { Corn } \\ \text { stover }\end{gathered}$

- Temperature: $200{ }^{\circ} \mathrm{C}$

Organosolv pretreatment

- Reactor volume: $2.5 \mathrm{~L}$

- $\quad$ Liquid to solid ratio: 10

- Solution: $50 \mathrm{vol} \%$ of ethanol

- Retention time: $60 \mathrm{~min}$

- Temperature: $182^{\circ} \mathrm{C}$

Dilute acid pretreatment

$\begin{array}{cll}\text { [75] } \begin{array}{cl}\text { Cotton stem } \\ \text { waste }\end{array} \quad \text { AD } \rightarrow \mathrm{PT} \rightarrow \mathrm{DSSF} \rightarrow \mathrm{DL} & \bullet & \mathrm{H}_{2} \mathrm{SO}_{4} \text { solution: } 4 \%(v / v) \\ & & \text { Temperature: } 200{ }^{\circ} \mathrm{C} \\ & \bullet & \text { Pressure: } 3-15 \text { atm } \\ & \bullet & \text { Retention time: } 2 \mathrm{~h}\end{array}$

\section{Steam pretreatment}

- Reactor volume: $10 \mathrm{~L}$

- Biomass load: $400 \mathrm{~g} \mathrm{DM}$

- Temperature: $190-210^{\circ} \mathrm{C}$

- Retention time: $10 \mathrm{~min}$
- Compared to the organosolv technique, biomass pretreated by steam explosion gave a higher production of both ethanol and biomethane.

- $\quad$ The steam explode biomass contributed $78.3 \%$ ethanol yield and additional biomethane of $120 \mathrm{~mL} / \mathrm{g}$ VS., while organosolv pretreated biomass gave $62.3 \%$ ethanol yield and $69 \mathrm{~mL}$ of biomethane/g VS.

The biofuel (bioethanol and biomethane) produced from the digested effluent accounted for $2.88 \mathrm{GJ} / \mathrm{t}$, which is $345 \%$ more energy than direct SHF of cotton stem wastes.

Maximum total product recovery was attained when SSF was conducted at 10 and 15\% initial water-insoluble solids, yielding 16.1-16.3 g ethanol, 5.8-6.0 g methane, and $25 \mathrm{~g}$ lignin-rich solid residue from $100 \mathrm{~g}$ dry wheat straw.

- The maximum equivalent gasoline (based on 1 ton of safflower straw) for the SC1 was 113.9 L (obtained from biomethane), produced after $1 \mathrm{~h}$ of pretreatment at 120 ${ }^{\circ} \mathrm{C}$ with $0.5 \mathrm{~mol} / \mathrm{L} \mathrm{Na}_{2} \mathrm{CO}_{3}$.

- $\quad$ For SC2, obtained from combining ethanol and biomethane, the maximum equivalent gasoline, on the basis of 1 ton of safflower straw, was $100 \mathrm{~L}$, as the biomass was pretreated by $1 \mathrm{~mol} / \mathrm{L}$ $\mathrm{Na}_{2} \mathrm{CO}_{3}$ at $180^{\circ} \mathrm{C}$ for $2 \mathrm{~h}$.

- With a $24 \mathrm{~h}$ delayed inoculation, though the DSSF method improved ethanol production rate by glucose inhibition, it was limited in the early phases of fermentation.

- $\quad$ Gradual hydrolyzed medium feeding with $30 \%(w / v)$ as solids loading at $96 \mathrm{~h}$ resulted in $68 \mathrm{~g} / \mathrm{L}(74.13 \%$ of theoretical yield) ethanol.

- $\quad$ Subsequent AD of stillage added 307 $\mathrm{mL} / \mathrm{g}$ VS. methane to the process. 
Table 1. Cont

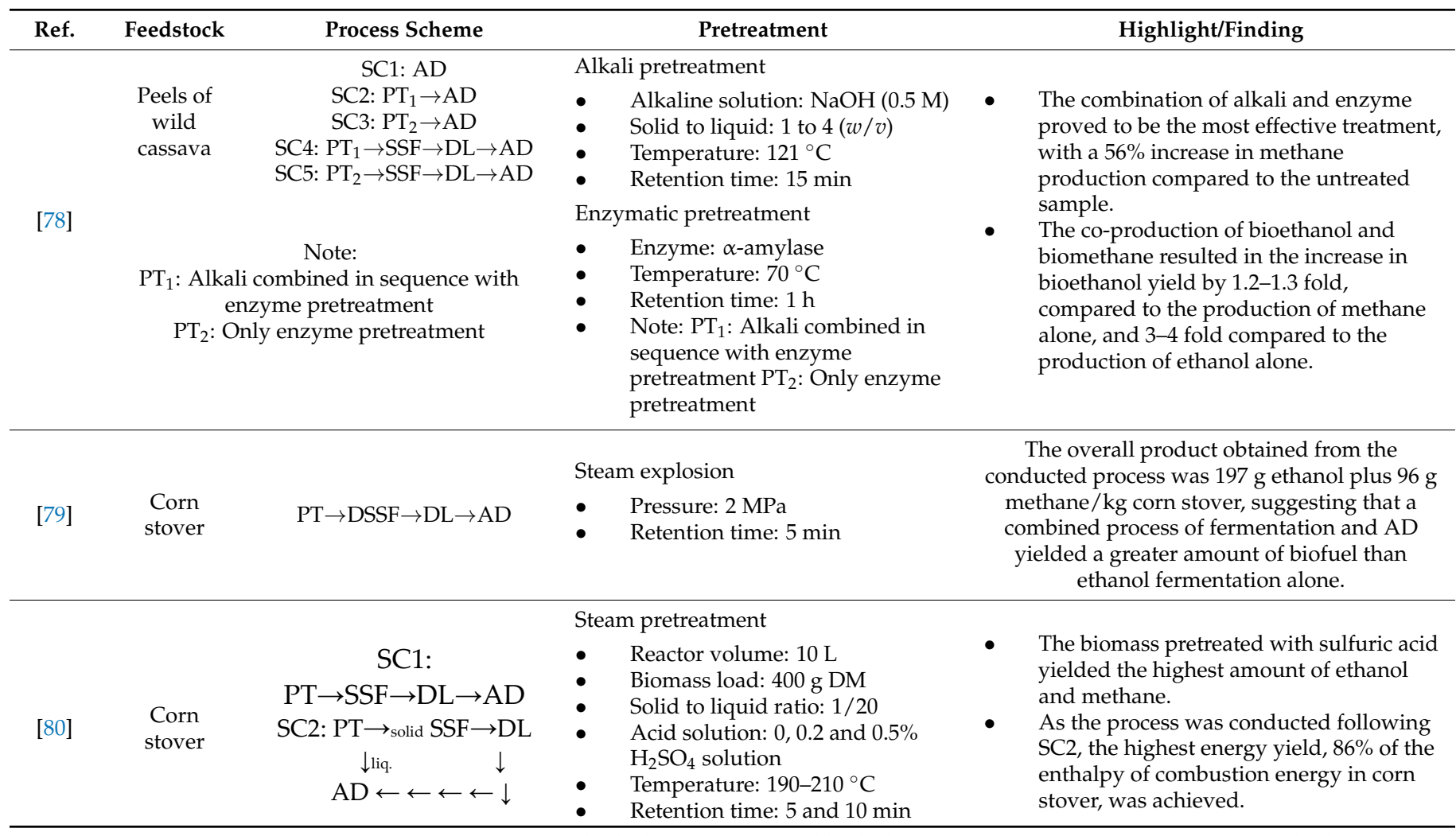

SC = Scenario, PT = Pretreatment, EHD = Enzymatic hydrolysis, AHD = Acid hydrolysis, FM = Fermentation, $\mathrm{SHF}=$ Separate hydrolysis and fermentation, SSF $=$ Simultaneous saccharification and fermentation, DSSF $=$ Delayed SSF, $\mathrm{AD}=\mathrm{Anaerobic}$ digestion, $\mathrm{DL}=\mathrm{Distillation}$.

\subsection{Net Energy Analysis of Co-Production of Second-Generation Bioethanol and Biogas}

Another key purpose of this research is to assess the approach to making the best use of lignocellulosic materials through effective co-production of bioethanol and biogas. One significant measure in this respect is the process's gross energy output. Figure 2 depicts the total energy output gathered from previous studies on such co-production processes, which can be classified into three schemes. In Scheme 1, the pretreated biomass is subjected to ethanol fermentation and, once the alcohol is recovered, the residue is directed to AD to produce biogas. Scheme 2 is similar to Scheme 1, except that biogas is produced from two sources: the residues from pretreatment and from ethanol fermentation. In Scheme 3, the biomass undergoes AD first, and the digested biomass is subsequently subjected to ethanol production. In other words, Scheme 3 is analogous to using AD as a pretreatment step prior to the production of ethanol [81].

In this review, the authors assessed the overall bioenergy output from the co-production processes by multiplying the amount of biofuels produced in each study with the corresponding lower heating value (LHV) given for bioethanol, biomethane, and biogas as $26.7 \mathrm{MJ} / \mathrm{kg}, 50.0 \mathrm{MJ} / \mathrm{kg}$, and $20.27 \mathrm{MJ} / \mathrm{kg}$, respectively. It can be seen from the figure that the co-production process produced approximately $7.99 \pm 2.50 \mathrm{MJ} /$ ton of dry biomass, which is equivalent to $249.54 \pm 78.08 \mathrm{~L}$ of gasoline, indicating a $142 \%$ and $70 \%$ increase in biofuel output compared to producing ethanol or biogas alone, respectively. In particular, Schemes 1 and 2, which enable bioethanol fermentation prior to AD, produce an average total energy output of $7.77 \pm 2.71$ and $9.79 \pm 1.47 \mathrm{MJ} /$ ton of dry biomass, respectively, while starting with AD, as in Scheme 3, results in a lower energy output of $6.38 \pm 1.68 \mathrm{MJ} /$ ton of dry biomass. The difference in energy output between co-production processes can be attributed to many factors, including raw material type, pretreatment techniques, and process conditions. According to Demichelis et al. (2020) [82], cassava produced more bioethanol and biogas than sugar or rice straw. Dererie et al. (2011) [83] discovered that pretreatment of oat straw with dilute acid impregnation overnight prior to steam explo- 
sion resulted in a significantly higher overall yield of bioethanol and biogas than steam explosion alone. Similarly, Papa et al. (2015) [84] reported that pretreatment under severe conditions yields more biofuels than mild pretreatments.

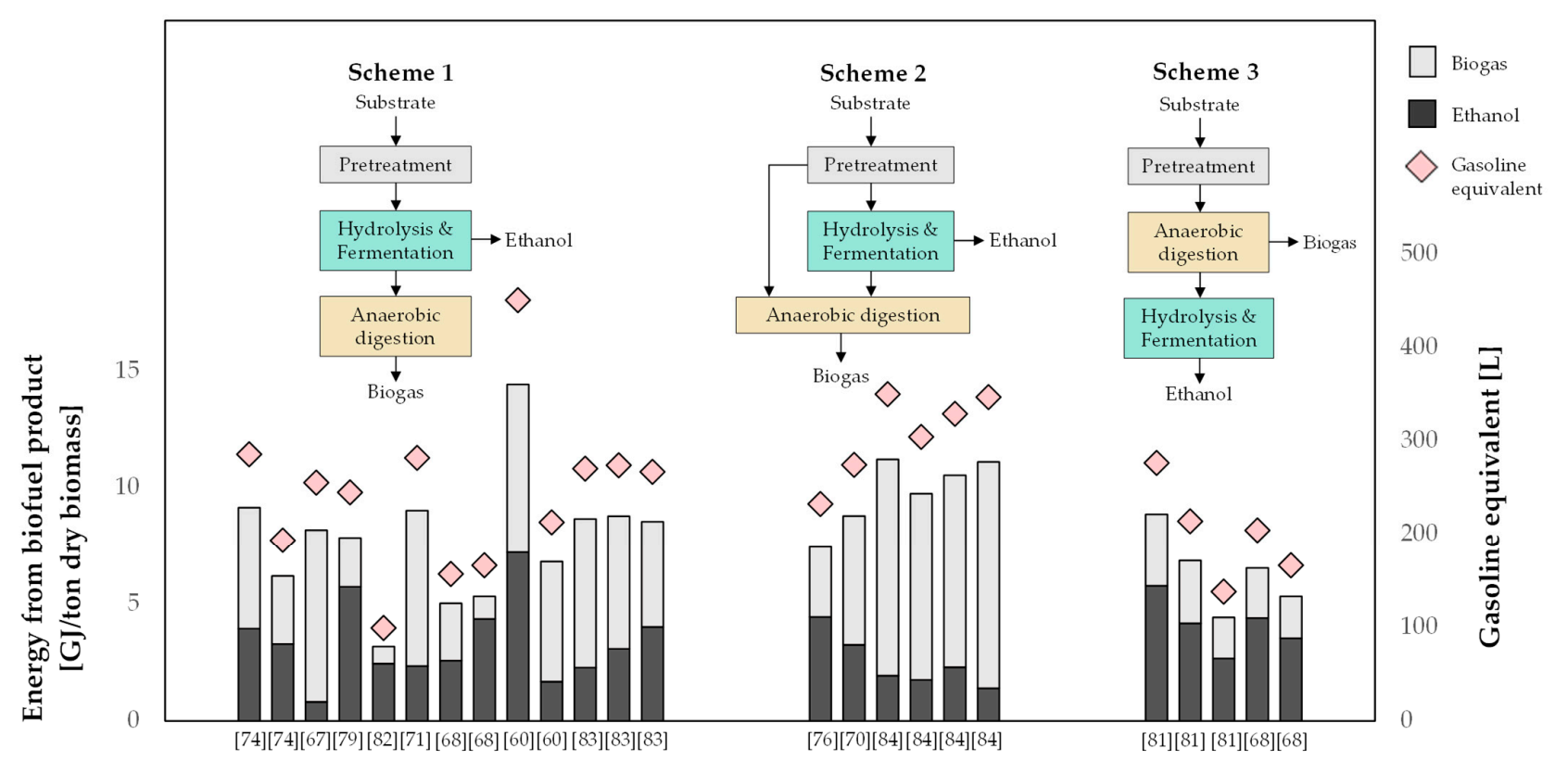

Reference

Figure 2. Gross energy output from studies on co-production of bioethanol and biogas from 2G biomass.

Along with these factors affecting biofuel productivity, the order of process is an intriguing factor to consider. Particularly, the high energy output in Scheme 2, where biogas is produced from both pretreatment and fermentation residues, is attributed to the preceding breakdown of macromolecules into smaller ones that can be readily converted to biogas. In this regard, Wu et al. (2021) [60] found that ethanol-fermented stillage produced approximately $20.7 \%$ more biomethane than that from the unfermented biomass used for the production of biogas alone. This is consistent with the findings from a study by Rocha-Meneses et al. (2019) [64], where biogas production was boosted by up to $34 \%$ using stillage as a substrate.

However, it is certain that the energy content of bioethanol and biogas varies depending on the order of the process. The scheme in which fermentation takes place prior to $\mathrm{AD}$ produces more biogas than ethanol, while starting off with $\mathrm{AD}$ provides the opposite result. This indicates that microbial degradation in the first step promotes better degradation in the subsequent process, particularly when ethanol is required as the main product. Conversely, the $\mathrm{AD}$ process primarily affects the breakdown of the hemicellulose network, which enhances cellulose conversion efficiency and results in higher ethanol yield. This is aligned with the results obtained from a study by Kaur et al. (2019) [68], which examined the effect of ethanol and biogas co-production sequences adopting three types of aquatic weed as feedstock. Therein, the ethanol yield obtained from hydrothermal pretreatment, followed by $\mathrm{AD}$ and fermentation, varied from $15.3-20.4 \mathrm{~g} / \mathrm{L}$, indicating $80.0-90.1 \%$ of theoretical ethanol yield. On the other hand, the lowest ethanol concentration obtained from the same pretreatment technique, followed by fermentation and $\mathrm{AD}$, was approximately $7.3-8.5 \mathrm{~g} / \mathrm{L}$, with no significant difference in methane yield given by the two process schemes.

It has been revealed by many past research studies that bioethanol production from lignocellulosic biomass requires 10-60\% more energy than starch-based and sugar-based feedstocks. The elevation in energy consumption results from the complexity of $2 \mathrm{G}$ biomass structures. Because of its complex structure, lignocellulosic biomass necessitates additional steps in order to be converted into fermentable sugars. Even when one $2 \mathrm{G}$ biomass is 
compared to another, the amount of energy required for this matter is quite different. Certainly, 2G biomass with more complex structures entails a greater investment in energy. According to a study by Demichelis et al. (2020) [82], the energy required for the production of bioethanol from rice straw and sugarcane was around 29-30 MJ/L EtOH, higher than that from potatoes and wheat straw, which were 17.7 MJ/L EtOH [82] and 12-15 MJ/L EtOH [76], respectively. Along with the complexity of the biomass, the solid content of the fermentation substrate also has an effect on the amount of energy consumed. Less solid content in the starting substrate results in a low ethanol concentration in the product, leading to the use of additional energy for subsequent ethanol purification.

While the co-production of bioethanol and biogas raises total energy output significantly, it also increases the complexity of the entire process. This implies that more energy is required to power additional manufacturing units, such as $\mathrm{AD}$ reactors and separation units for value-added product recovery. To date, there are still a limited number of studies on net energy analysis of this co-production process. Furthermore, the findings from each research were quite varied due to the differences between the given definitions of indicators such as net energy value, net energy ratio [82], energy efficiency [76], and energy yield [85], as summarized in Table 2. In this review, two approaches to net energy analysis are discussed.

1. Net energy analyses were performed by comparing the heating value of the product outputs to the biomass inputs, which, in some studies, also included the heating values of the chemicals used in the process.

2. Net energy analyses were carried out by comparing the heating value of the product outputs to all the energy utilized in the process, including feedstocks, electricity, steam, etc.

Table 2. Energy efficiency indicators used in net energy analysis of co-production of $2 \mathrm{G}$ bioethanol and biogas.

\begin{tabular}{|c|c|c|}
\hline Ref. & Process Detail and Energy Potential Parameter & Calculation and Result \\
\hline [60] & $\begin{array}{l}\text { - } \quad \text { Substrate: Pennisetum purpureum } \\
\text { - } \quad \text { Pretreatment: ensiling pretreatment and } \mathrm{NaOH} \\
\text { pretreatment } \\
\text { - } \quad \text { Process: enzymatic hydrolysis followed by ethanol } \\
\text { - } \quad \text { Prmentation and AD for biogas } \\
\text { Product: ethanol and biogas }\end{array}$ & $\begin{array}{l}\text { Energy conversion efficiency }=\frac{\text { Energy output }}{\text { Energy input }} \times 100 \\
\qquad=81.3-73.4 \% \\
\text { Note: Energy input denotes the heating value of raw material and } \\
\text { Energy output is the energy of produced ethanol and biogas }\end{array}$ \\
\hline [76] & $\begin{array}{l}\text { - } \quad \text { Substrate: wheat straw } \\
\text { - } \quad \text { Pretreatment: impregnated with acetic acid } \\
\text { - } \quad \text { Product: ethanol, biogas, and dry pellets }\end{array}$ & $\begin{array}{c}\text { Energy Efficiency }=\frac{\text { Heating value of product }}{\text { Heating value of all input materials }} \times 100 \\
=68-72 \% \\
\text { Note: Input materials include raw materials }+ \text { molasses }+ \text { enzyme }+ \\
\text { harvest and transportation }\end{array}$ \\
\hline [82] & $\begin{array}{l}\text { - } \quad \text { Substrate: rice straw } \\
\text { Pretreatment: diluted acid pretreatment at } 121^{\circ} \mathrm{C} \\
\text { - } \quad \text { for } 15 \text { min } \\
\text { Process: enzymatic hydrolysis followed by ethanol } \\
\text { fermentation and AD } \\
\text { Product: ethanol and biogas (used in process) }\end{array}$ & 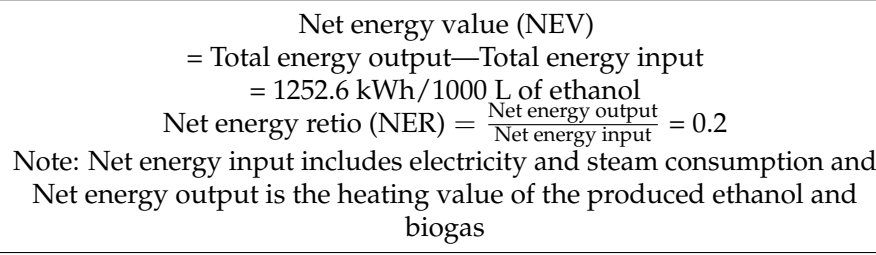 \\
\hline [68] & $\begin{array}{l}\text { - } \quad \text { Substrate: aquatic weeds } \\
\text { Pretreatment: hydrothermal pretreatment at } 121^{\circ} \mathrm{C} \\
\text { - } \quad 15 \text { min } \\
\text { Process: SSF for ethanol and AD for biogas } \\
\text { - } \quad \text { Product: ethanol and biogas }\end{array}$ & $\begin{array}{l}\text { Energy retio }=\frac{\text { Total energy output }}{\text { Total energy input }}=1.7-2.1 \\
\text { Note: Total energy input includes heat and electricity for process } \\
\text { equipment and Total energy output is the heating value of produced } \\
\text { ethanol and biogas. }\end{array}$ \\
\hline [86] & $\begin{array}{ll} & \text { Substrate: pinewood } \\
\text { - } & \text { Pretreatment: steam } \\
& \text { explosion/N-methylmorpholine-N-oxide } \\
\text { - } & \text { Process: ethanol fermentation and AD for biogas } \\
\text { - } & \text { Product: ethanol and biogas }\end{array}$ & $\begin{array}{l}\mathrm{R}_{\mathrm{O} / \mathrm{I}}=\frac{\mathrm{EO}}{\text { Heating } \sum \mathrm{EI}}=75.64-77.46 \% \\
\text { Note: } \mathrm{RO} / \mathrm{I} \text { denotes the energy output-to-input ratio; } \\
\text { EO is heating value of the products; and EI is energy inputs, including } \\
\text { electricity, low and high pressure steam, and heating values of the raw } \\
\text { materials. }\end{array}$ \\
\hline [87] & $\begin{array}{ll} & \text { Substrate: spruce wood } \\
\text { - } & \text { Pretreatment: steam } \\
& \text { explosion/N-methylmorpholine-N-oxide } \\
\text { - } & \text { Process: ethanol fermentation and AD for biogas } \\
\text { - } & \text { Product: ethanol, biogas, and lignin } \\
\end{array}$ & $\begin{array}{c}\text { Energy Efficiency }=\frac{\text { Heating value of product }}{\text { Heating value of all input materials }} \times 100 \\
=79 \% \\
\text { Note: Input materials are raw materials + electricity + steam }\end{array}$ \\
\hline
\end{tabular}


The results obtained from this approach vary significantly, depending on the different ways of energy estimation applied to each production step. In addition, some studies have utilized the produced biogas and solid residues to generate the energy used within the process, and thus energy costs were subtracted. Bittencourt et al. (2019) [88] reported that the biogas generated in the co-production process is sufficient as a heat source for hydrothermal pretreatment and the drying of pretreated biomass, which consumed 1.65 and $1.72 \mathrm{MJ} / \mathrm{kg}$ of biomass, respectively.

However, most of the studies came to the same conclusion, that the most energyconsuming steps are those involving the use of intensive heat, including pretreatments (hydrothermal and thermochemical methods, in particular) and product purification. Comparing the energy used in five biomass pretreatment methods, it was found that organosolvent (OS) consumed the highest energy, reaching 15.07 GJ/ton of biomass, followed by ammonia fiber explosion (AFEX), liquid hot water (LHW), steam explosion (SE), and dilute acid (DA), which took up 8.34,5.62, 4.84, and $4.24 \mathrm{GJ} /$ ton of biomass, respectively [89]. The high energy consumption for OS and AFEX methods was a consequence of the need for intensive heat to separate the chemicals for reuse. This corresponds to a study conducted by Conde-Mejia et al. (2012) [90], which reported that the energy used for OS pretreatment could reach up to 11.6 GJ/ton of biomass. According to Kaur et al. (2019) [68], energy dissipated during distillation accounts for up to 30-37\% of total energy consumed in the co-production of bioethanol and biogas from 2G biomass. Hydrolysis (especially with enzymes), fermentation, and AD, on the other hand, require considerably less energy, only for powering agitators and transfer pumps [86].

\subsection{Techno-Economic Assessment of Co-Production of Second-Generation Bioethanol and Biogas}

Techno-economic analysis is a critical step that will move laboratory research toward industrial production. In this regard, many studies on the cost-effectiveness of ethanol production from lignocellulosic biomass have been conducted over the last two decades. According to a study by The National Renewable Energy Laboratory (NREL), the minimum ethanol selling price (MESP) produced from 2G biomass in 1999 was approximately USD $0.38 / \mathrm{L}$. Later, as the production technology became more advanced, various factors used in the assessment, such as equipment prices and installation costs, were updated to be more consistent with the present conditions. In 2011, the NREL estimated that the MESP would be approximately USD $0.57 / \mathrm{L}$ [91]. However, MESP results from other research studies vary widely and are somewhat different from those assessed by the NREL, despite the adoption of factors and assumptions from the NREL study.

In the economic assessment of the production of ethanol alone, using sugarcane and sweet sorghum bagasse, van Rijn et al. (2018) [92] found that MESPs lay in the range of $0.24-1.21 / \mathrm{L}$. They revealed that these variations are a consequence of process configuration, substrate and enzyme costs, and production yield, as well as total capital investment (TCI), total operating cost (TOC), and other invisible expenses. In this regard, the authors have compiled important indicators for techno-economic analysis as well as the assumptions used in past studies, as given in Table 3. MESP is a critical indicator that is frequently used to determine the economic feasibility of ethanol production. It denotes the lowest selling price of ethanol while maintaining the project's net present value (NPV) at zero [92].

Figure 3 shows the MESPs of various methods employed to produce bioethanol from lignocellulosic materials. It can be seen from the figure that the MESPs range from USD 0.27 to $1.8 / \mathrm{L}$, with an average of USD $0.82 \pm 0.44 / \mathrm{L}$, which is $28 \%$ higher than the market price of ethanol (USD 0.59/L, as of August 2021). Although MESPs in previous studies came out differently, most of them came to the same conclusion in the sense that the key factors most affecting MESPs are the cost of raw materials and the pretreatment methods used. For instance, Barrera et al. (2015) [93] calculated the cost of producing ethanol from sugarcane bagasse and blue agave bagasse and found that the price of raw materials took up the greatest proportion of the production cost, accounting for $35 \%$ of the total. In the economic assessment of ethanol production from different biomass (sugarcane 
bagasse, coffee cut-stems, rice husk, and palm empty fruit bunches) by Quintero et al. (2013) [94], the determined MESPs were USD 0.58-0.77/L. Therein, bioethanol derived from palm empty fruit bunches presented the lowest MESP as it possesses the lowest cost of feedstock. The study also concluded that if the fermentation residues were used to generate energy via a cogeneration system, MESPs could be reduced by up to $17 \%$. Demichelis et al. (2020) [82] assessed the cost benefit of co-production of bioethanol and biogas from different substrates. As expected, using sugar-based materials (sugarcane) is more profitable than using lignocellulosic biomass (rice straw), resulting in $89.4 \%$ and $50.3 \%$ lower NPV and ROI of ethanol production from rice straw than from sugarcane, respectively.

Table 3. Assumptions used in techno-economic assessment of co-production of $2 \mathrm{G}$ bioethanol and biogas (data summarized from $[61,76,92,95-97])$.

\begin{tabular}{|c|c|c|}
\hline $\begin{array}{l}\text { Fixed Capital Investment (FCI) } \\
\text { Total Capital Investment Cost (TCI) }\end{array}$ & $\begin{array}{l}=\mathrm{TDC}+\mathrm{TIC} \\
=\mathrm{FCI}+\text { Land Cost }+ \text { Working Capital }\end{array}$ & \\
\hline $\begin{array}{l}\text { Total direct cost (TDC) } \\
=\text { Listed equipment cost }+ \text { Unlisted equipment cost }+ \\
\text { Inside battery limits (ISBL) cost }+ \text { Warehouse cost }+ \text { Site } \\
\text { development cost }+ \text { Additional piping cost }+ \text { Startup cost }\end{array}$ & $\begin{array}{l}\text { Unlisted equipment cost } \\
\text { Installation cost } \\
\text { Warehouse cost } \\
\text { Site development cost } \\
\text { Additional piping cost }\end{array}$ & $\begin{array}{l}=20 \% \text { of listed equipment cost } \\
=42 \% \text { of listed and unlisted equipment } \\
=4 \% \text { of ISBL } \\
=9 \% \text { of ISBL } \\
=4.5-10 \% \text { of ISBL }\end{array}$ \\
\hline $\begin{array}{l}\text { Total indirect cost (TIC) } \\
=\text { Other expenses for starting up }\end{array}$ & $\begin{array}{l}\text { Field Expenses } \\
\text { Auxiliary facilities } \\
\text { Project contingency } \\
\text { Working capital } \\
\text { Startup cost } \\
\text { Other cost }\end{array}$ & $\begin{array}{l}=10 \% \text { of TDC } \\
=15-20 \% \text { of TDC } \\
=10 \% \text { of TDC } \\
=5-10 \% \text { of FCI } \\
=5-10 \% \text { of FCI } \\
=10-12 \% \text { of TDC }\end{array}$ \\
\hline Other assumptions for plant & $\begin{array}{l}\text { Investment lifetime } \\
\text { Construction and Starting period } \\
\text { Construction cost }\end{array}$ & $\begin{array}{l}=20-30 \text { years } \\
=3 \text { years } \\
=32 \%(1 \text { st year), } 60 \% \text { (2nd year) and } 8 \% \\
\text { (3rd year) }\end{array}$ \\
\hline Total operating cost (TOC) & \multicolumn{2}{|c|}{$=$ Materials cost + Labor cost + Utility cost + Facility dependent cost } \\
\hline $\begin{array}{l}\text { Facility dependent cost } \\
\text { =Maintenance cost }+ \text { Depreciation cost }+ \text { Insurance cost }+ \\
\text { Local taxes + Factory expenses }\end{array}$ & $\begin{array}{l}\text { Maintenance cost } \\
\text { Insurance cost } \\
\text { Local taxes } \\
\text { Factory expenses }\end{array}$ & $\begin{array}{l}=10 \% \text { of equipment cost } \\
=1 \% \text { of } \mathrm{FCI} \\
=2 \% \text { of } \mathrm{FCI} \\
=5 \% \text { of } \mathrm{FCI}\end{array}$ \\
\hline Feedstock and utilities cost & $\begin{array}{l}\text { Electricity cost } \\
\text { Steam cost (low pressure) } \\
\text { Steam cost (high pressure) } \\
\text { Cooling water cost } \\
\text { Chilled water cost } \\
\text { Labor cost }\end{array}$ & $\begin{array}{l}=\text { USD } 0.07-0.1 / \mathrm{kWh} \\
=\text { USD } 3 / \text { ton } \\
=\text { USD } 8 / \text { ton } \\
=\text { USD } 0.05 / \text { ton } \\
=\text { USD } 0.4 / \text { ton } \\
=\text { USD } 1.74 / \mathrm{h}\end{array}$ \\
\hline Others & $\begin{array}{l}\text { Loan interest } \\
\text { Income tax rate } \\
\text { Discount rate }\end{array}$ & $\begin{array}{l}=8 \% \\
=35 \% \\
=10-12 \%\end{array}$ \\
\hline
\end{tabular}

As expected, using lignocellulosic biomass (rice straw) to produce ethanol was less profitable than sugar-based materials (sugarcane), as an $89.4 \%$ and $50.3 \%$ decrease in NPV and ROI, respectively, were presented. Da Silva et al. (2016) [98] found that the difference in energy used in different pretreatment processes, liquid hot water (LHW) and ammonia fiber explosion (AFEX), caused varying MESPs, ranging from USD 1.78-2.47/L. Similarly, Zang (2020) [99] indicated that, in the co-production of ethanol, furfural, and lignin from switchgrass, the pretreatment (fractionation) cost accounted for $35.5 \%$ of the total production, being the most expensive step, followed by feedstock cost as the second most expensive.

Efforts to reduce the MESP of $2 \mathrm{G}$ ethanol, allowing it to be competitive with $1 \mathrm{G}$ ethanol, have been demonstrated in many studies on the production of ethanol alone. Therein, incinerating high lignin content solid residues resulted in a certain amount of energy that could be supplemental to the main process. However, it appears that relying on solid residues alone may not be sufficient to reduce the MESP of $2 \mathrm{G}$ ethanol to the desired level. These additional products came in two forms, including (1) energy and fuel to 
supplement the main process, such as heat and biogas, and (2) by-products to supplement revenue, such as furfural, xylitol, and fertilizer. The co-production process resulted in an average MESP $16 \%$ lower than the MESP obtained from individual productions, which were USD 0.75 and USD $0.89 / \mathrm{L}$, respectively. In addition to using biogas derived from co-production, as a supplemental fuel, Gubicza et al. (2016) [91] found another way to top up the revenue by making use of liquid fraction residues as fertilizers, bringing the MESP to USD $0.5 / \mathrm{L}$, which was even lower than the ethanol market price.

Hossain et al. (2019) [100] studied a co-production process producing ethanol along with furfural that was separated after pretreatment. The separation of furfural, a fermentation inhibitor, increases not only the ethanol yield but also the NPV of the entire project from the USD 1700/ton furfural sale. Bbosa (2018) [101] studied the co-production of ethanol with other valuable chemicals such as catechol, phenol, cresols, acetic acid, formic acid, furfural, and acetaldehyde from lignin that was separated after hydrothermal liquefaction, achieving the lowest MESP of USD $0.27 \pm 0.08 / \mathrm{L}$.

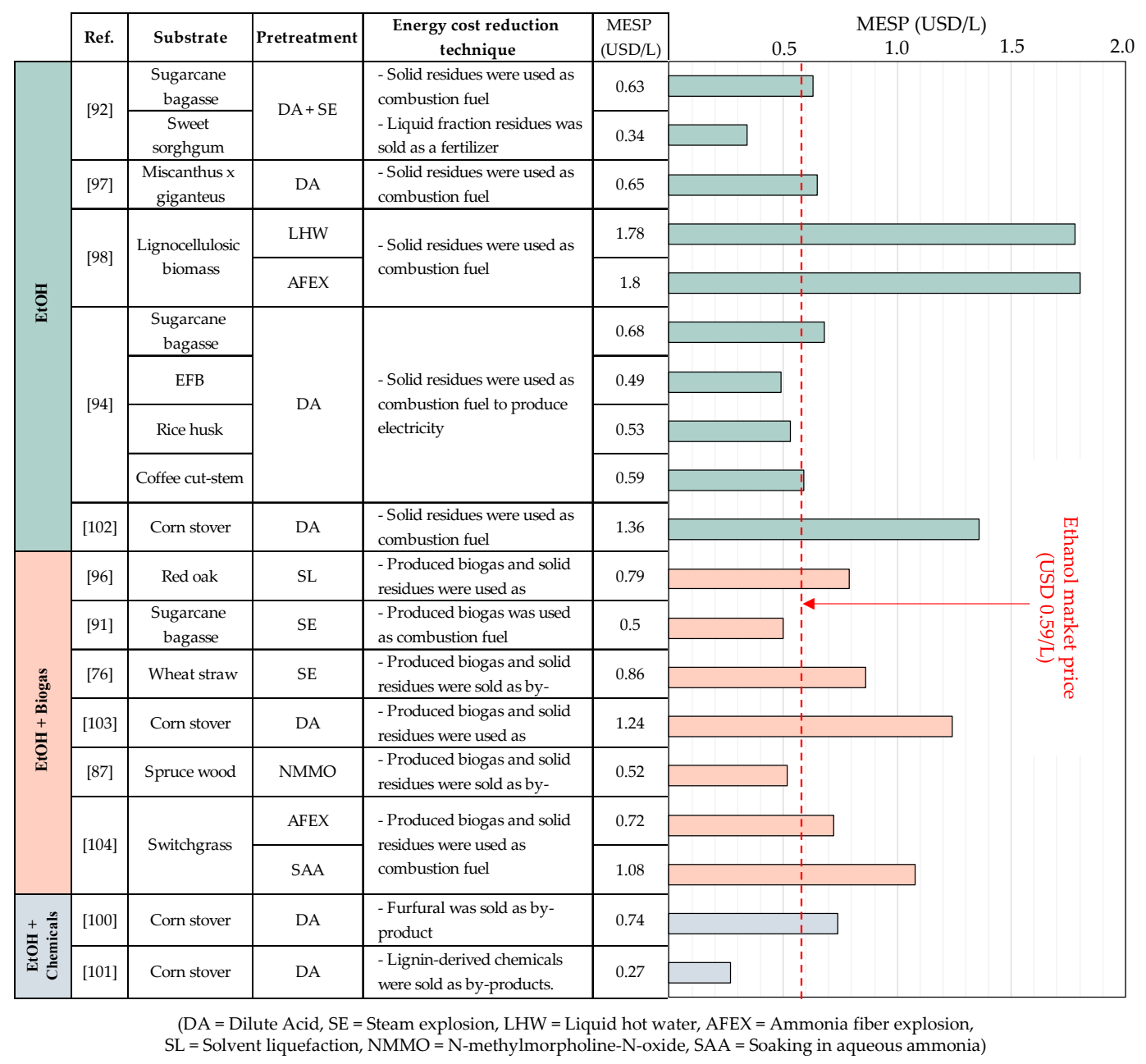

Figure 3. MESPs from various methods employed for the production of bioethanol from $2 \mathrm{G}$ biomass. Previous research has demonstrated that in order for the MESP of ethanol produced from lignocellulosic material to compete with that of conventional ethanol, additional utilization of the production process residue is required. This includes direct incineration of the residue as a solid fuel, which provides additional heat for the process, as well as the production of secondary high-value products. However, despite the utilization of residue from the process, the MESP of $2 \mathrm{G}$ bioethanol remains significantly higher than the ethanol market price in many studies [98,102-104]. This indicates the need for additional research into the production of ethanol from lignocellulosic biomass in order to increase production efficiency. Additionally, complementary policies such as carbon taxes and incentives may be implemented [105]. 


\section{Conclusions and Path Forward}

From higher global energy demands to the massive release of GHGs, the need for clean energy to replace fossil fuels is increasingly becoming apparent. This review highlights the potential of turning waste lignocellulosic biomass into versatile green fuels such as ethanol. Prior research efforts in the field of ethanol production from lignocellulosic materials have focused on improving the production yield by modifying the pretreatment process, which is referred to as the stage that determines the overall success of production. On an industrial scale, simple and non-severe pretreatments such as mechanical pretreatment, chemical pretreatment, and biological pretreatment are typically used. However, because lignin, a major barrier to hydrolysis and fermentation, is not sufficiently removed by these methods, the resulting ethanol yield is still unsatisfactory.

By combining the advantages of several methods, more advanced pretreatment techniques, such as ultrasound-assisted chemical treatment, microwave-assisted chemical treatment, and steam explosion, have emerged. However, the more complicated the techniques, the more energy is consumed, and the investment costs rise. Therefore, most of these methods are still in the early stages of development. At this point, the co-production of multiple products has gained interest due to the remaining value in the ethanol production residue. The most common scheme is to convert the residues to energy as this does not require a significant modification to the process. Solid residues with a high lignin content, in particular, retain a high calorific value and can be used directly as a source of heat to supplement the main process. Through the AD process, stillage can be converted to biogas, which can then be used as a fuel for electricity and heat generation, allowing for a $2-3$ fold increase in energy output. Additionally, co-production may be directed toward other high-value chemicals, such as catechol, phenol, cresols, acetic acid, formic acid, furfural, and acetaldehyde and so on.

Techno-economic studies have demonstrated that the co-production process reduces the MESP to close to the ethanol market price, implying the possibility of industrializing the production of cellulosic ethanol as a substantial alternative to fossil fuels. However, because most of the findings in this review are based on simulations, additional research, development, and running tests at both pilot and industrial scales are necessary to ensure additional investor confidence.

Author Contributions: Conceptualization, C.P. and T.J.; validation, C.P.; formal analysis, T.J.; writing—original draft preparation, C.P. and T.J.; writing—review and editing, C.P.; supervision, C.P. All authors have read and agreed to the published version of the manuscript.

Funding: This research is funded by Chulalongkorn University: CU_GR_63_49_64_01.

Institutional Review Board Statement: Not applicable.

Informed Consent Statement: Not applicable.

Data Availability Statement: Not applicable.

Conflicts of Interest: The authors declare no conflict of interest.

\section{References}

1. Lamb, W.F.; Wiedmann, T.; Pongratz, J.; Andrew, R.; Crippa, M.; Olivier, J.G.; Wiedenhofer, D.; Mattioli, G.; Al Khourdajie, A.; House, J.; et al. A review of trends and drivers of greenhouse gas emissions by sector from 1990 to 2018. Environ. Res. Lett. 2021, 16, 073005. [CrossRef]

2. Andersson, Ö.; Börjesson, P. The greenhouse gas emissions of an electrified vehicle combined with renewable fuels: Life cycle assessment and policy implications. Appl. Energy 2021, 289, 116621. [CrossRef]

3. Aro, E.M. From first generation biofuels to advanced solar biofuels. Ambio 2016, 45, 24-31. [CrossRef] [PubMed]

4. Jacquet, N.; Haubruge, E.; Richel, A. Production of biofuels and biomolecules in the framework of circular economy: A regional case study. Waste Manag. Res. 2015, 33, 1121-1126. [CrossRef] [PubMed]

5. Liu, Y.; Cruz-Morales, P.; Zargar, A.; Belcher, M.S.; Pang, B.; Englund, E.; Dan, Q.; Yin, K.; Keasling, J.D. Biofuels for a sustainable future. Cell 2021, 184, 1636-1647. [CrossRef] [PubMed] 
6. Lewandrowski, J.; Rosenfeld, J.; Pape, D.; Hendrickson, T.; Jaglo, K.; Moffroid, K. The greenhouse gas benefits of corn ethanolassessing recent evidence. Biofuels 2020, 11, 361-375. [CrossRef]

7. Suarez-Bertoa, R.; Zardini, A.A.; Keuken, H.; Astorga, C. Impact of ethanol containing gasoline blends on emissions from a flex-fuel vehicle tested over the Worldwide Harmonized Light duty Test Cycle (WLTC). Fuel 2015, 143, 173-182. [CrossRef]

8. Niphadkar, S.; Bagade, P.; Ahmed, S. Bioethanol production: Insight into past, present and future perspectives. Biofuels 2018, 9, 229-238. [CrossRef]

9. Anwar, Z.; Gulfraz, M.; Irshad, M. Agro-industrial lignocellulosic biomass a key to unlock the future bio-energy: A brief review. J. Radiat. Res. Appl. Sci. 2014, 7, 163-173. [CrossRef]

10. Valenti, F.; Porto, S.M.C.; Cascone, G.; Arcidiacono, C. Potential biogas production from agricultural by-products in Sicily. A case study of citrus pulp and olive pomace. J. Agric. Eng. 2017, 48, 196-202. [CrossRef]

11. Achinas, S.; Achinas, V.; Euverink, G.J.W. A technological overview of biogas production from biowaste. Engineering 2017, 3 , 299-307. [CrossRef]

12. Vollmer, N.I. Sustainable Value Chain Design for Biorefineries. Abstract from KT Consortium Annual Meeting, Helsingør, Denmark. 2019. Available online: https://backend.orbit.dtu.dk/ws/portalfiles/portal/206223786/Abstract_nikov_2019_2.pdf (accessed on 5 June 2021).

13. Liu, Y.; Xu, J.; Zhang, Y.; Yuan, Z.; He, M.; Liang, C.; Zhuang, X.; Xie, J. Sequential bioethanol and biogas production from sugarcane bagasse based on high solids fed-batch SSF. Energy 2015, 90, 1199-1205. [CrossRef]

14. Welch, P.; Scopes, R.K. Studies on cell-free metabolism: Ethanol production by a yeast glycolytic system reconstituted from purified enzymes. J. Biotechnol. 1985, 2, 257-273. [CrossRef]

15. Singh, A.K.; Garg, N.; Tyagi, A.K. Viable feedstock options and technological challenges for ethanol production in India. Curr. Sci. 2016, 111, 815-822. [CrossRef]

16. Lee, R.A.; Lavoie, J.M. From first-to third-generation biofuels: Challenges of producing a commodity from a biomass of increasing complexity. Anim. Front. 2013, 3, 6-11. [CrossRef]

17. Galbe, M.; Wallberg, O.; Zacchi, G. Techno-economic aspects of ethanol production from lignocellulosic agricultural crops and residues. In Comprehensive Biotechnology, 2nd ed.; Young, M., Ed.; Pergamon Press: Oxford, UK, 2011; pp. 615-628.

18. Öhgren, K.; Bura, R.; Lesnicki, G.; Saddler, J.; Zacchi, G. A comparison between simultaneous saccharification and fermentation and separate hydrolysis and fermentation using steam-pretreated corn stover. Process Biochem. 2007, 42, 834-839. [CrossRef]

19. Qin, L.; Li, W.C.; Liu, L.; Zhu, J.Q.; Li, X.; Li, B.Z.; Yuan, Y.J. Inhibition of lignin-derived phenolic compounds to cellulase. Biotechnol. Biofuels 2016, 9, 70. [CrossRef]

20. Jing, X.; Zhang, X.; Bao, J. Inhibition performance of lignocellulose degradation products on industrial cellulase enzymes during cellulose hydrolysis. Appl. Biochem. Biotechnol. 2009, 159, 696-707. [CrossRef]

21. Olofsson, K.; Bertilsson, M.; Lidén, G. A short review on SSF-An interesting process option for ethanol production from lignocellulosic feedstocks. Biotechnol. Biofuels 2008, 1, 7. [CrossRef] [PubMed]

22. Dien, B.S. Mass balances and analytical methods for biomass pretreatment experiments. In Biomass to Biofuels: Strategies for Global Industries; Vertes, A.A., Qureshi, N., Blaschek, H.P., Yukawa, H., Eds.; Wiley: New York, NY, USA, 2010; pp. $213-231$.

23. Rulli, M.C.; Bellomi, D.; Cazzoli, A.; De Carolis, G.; D'Odorico, P. The water-land-food nexus of first-generation biofuels. Sci. Rep. 2016, 6, 22521. [CrossRef]

24. Lavoie, J.M.; Beauchet, R.; Berberi, V.; Chornet, M. Biorefining lignocellulosic biomass via the feedstock impregnation rapid and sequential steam treatment. Biofuels Eng. Process Technol. 2008, 687-714.

25. Tarasov, D.; Leitch, M.; Fatehi, P. Lignin-carbohydrate complexes: Properties, applications, analyses, and methods of extraction: A review. Biotechnol. Biofuels 2018, 11, 269. [CrossRef]

26. Zeng, Y.; Zhao, S.; Yang, S.; Ding, S.Y. Lignin plays a negative role in the biochemical process for producing lignocellulosic biofuels. Curr. Opin. Biotechnol. 2014, 27, 38-45. [CrossRef] [PubMed]

27. Maurya, D.P.; Singla, A.; Negi, S. An overview of key pretreatment processes for biological conversion of lignocellulosic biomass to bioethanol. 3 Biotech 2015, 5, 597-609. [CrossRef] [PubMed]

28. Baruah, J.; Nath, B.K.; Sharma, R.; Kumar, S.; Deka, R.C.; Baruah, D.C.; Kalita, E. Recent trends in the pretreatment of lignocellulosic biomass for value-added products. Front. Energy Res. 2018, 6, 141. [CrossRef]

29. De Lima, D.R.; Silveira, M.H.L.; Del Rio, L.; Ramos, L.P. Pretreatment processes for cellulosic ethanol production: Processes integration and modeling for the utilization of lignocellulosics such as sugarcane straw. In Green Fuels Technology; Soccol, C.R., Brar, S.K., Faulds, C., Ramos, L.P., Eds.; Springer: Cham, Switzerland, 2016; pp. 107-131.

30. Keskin, T.; Abubackar, H.N.; Arslan, K.; Azbar, N. Chapter 12-Biohydrogen Production from Solid Wastes, Biohydrogen. In Biomass, Biofuels, Biochemicals: Biohydrogen, 2nd ed.; Elsevier: Amsterdam, The Netherlands, 2019; pp. 321-346.

31. Solarte-Toro, J.C.; Romero-García, J.M.; Martínez-Patiño, J.C.; Ruiz-Ramos, E.; Castro-Galiano, E.; Cardona-Alzate, C.A. Acid pretreatment of lignocellulosic biomass for energy vectors production: A review focused on operational conditions and technoeconomic assessment for bioethanol production. Renew. Sust. Energy Rev. 2019, 107, 587-601. [CrossRef]

32. Bensah, E.C.; Mensah, M. Chemical pretreatment methods for the production of cellulosic ethanol: Technologies and innovations. Int. J. Chem. Eng. 2013, 2013, 719607. [CrossRef]

33. Jönsson, L.J.; Martín, C. Pretreatment of lignocellulose: Formation of inhibitory by-products and strategies for minimizing their effects. Bioresour. Technol. 2016, 199, 103-112. [CrossRef] 
34. Kong, F.; Engler, C.R.; Soltes, E.J. Effects of cell-wall acetate, xylan backbone, and lignin on enzymatic hydrolysis of aspen wood. Appl. Biochem. Biotechnol. 1992, 34, 23-35. [CrossRef]

35. Bals, B.; Rogers, C.; Jin, M.; Balan, V.; Dale, B. Evaluation of ammonia fibre expansion (AFEX) pretreatment for enzymatic hydrolysis of switchgrass harvested in different seasons and locations. Biotechnol. Biofuels 2010, 3, 1-11. [CrossRef]

36. Kai, D.; Tan, M.J.; Chee, P.L.; Chua, Y.K.; Yap, Y.L.; Loh, X.J. Towards lignin-based functional materials in a sustainable world. Green Chem. 2016, 18, 1175-1200. [CrossRef]

37. Mankar, A.R.; Pandey, A.; Modak, A.; Pant, K. Pre-treatment of Lignocellulosic Biomass: A Review on Recent Advances. Bioresour. Technol. 2021, 334, 125235. [CrossRef] [PubMed]

38. Swatloski, R.P.; Spear, S.K.; Holbrey, J.D.; Rogers, R.D. Dissolution of cellose with ionic liquids. J. Am. Chem. Soc. 2002, 124, 4974-4975. [CrossRef] [PubMed]

39. Li, C.; Cheng, G.; Balan, V.; Kent, M.S.; Ong, M.; Chundawat, S.P.; daCosta Sousa, L.; Melnichenko, Y.B.; Dale, B.E.; Simmons, B.A.; et al. Influence of physico-chemical changes on enzymatic digestibility of ionic liquid and AFEX pretreated corn stover. Bioresour. Technol. 2011, 102, 6928-6936. [CrossRef] [PubMed]

40. Zheng, Y.; Shi, J.; Tu, M.; Cheng, Y.S. Principles and development of lignocellulosic biomass pretreatment for biofuels. Adv. Bioenergy 2017, 2,1-68. [CrossRef]

41. Vasco-Correa, J.; Ge, X.; Li, Y. Biological pretreatment of lignocellulosic biomass. In Biomass Fractionation Technologies for a Lignocellulosic Feedstock Based Biorefinery; Mussatto, S.I., Ed.; Elsevier: Amsterdam, The Netherlands, 2016; pp. 561-585.

42. Chaturvedi, V.; Verma, P. An overview of key pretreatment processes employed for bioconversion of lignocellulosic biomass into biofuels and value added products. 3 Biotech 2013, 3, 415-431. [CrossRef]

43. Patel, A.; Shah, A. Integrated lignocellulosic biorefinery: Gateway for production of second generation ethanol and value added products. J. Bioresour. Bioprod. 2021, 6, 108-128. [CrossRef]

44. Sjulander, N.; Kikas, T. Origin, impact and control of lignocellulosic inhibitors in bioethanol production-A review. Energies 2020, 13, 4751. [CrossRef]

45. Liu, T.; Li, Z. An electrogenerated base for the alkaline oxidative pretreatment of lignocellulosic biomass to produce bioethanol. RSC Adv. 2017, 7, 47456-47463. [CrossRef]

46. Liu, X.; Xu, W.; Mao, L.; Zhang, C.; Yan, P.; Xu, Z.; Zhang, Z.C. Lignocellulosic ethanol production by starch-base industrial yeast under PEG detoxification. Sci. Rep. 2016, 6, 20361. [CrossRef]

47. Mikkola, J.P.; Sklavounos, E.; King, A.W.; Virtanen, P. The biorefinery and green chemistry. In RSC Green Chemistry No. 36 Ionic Liquids in the Biorefinery Concept: Challenges and Perspectives; Lukasik, R.B., Ed.; The Royal Society of Chemistry: Cambridge, UK, 2015; pp. 1-37.

48. Rosales-Calderon, O.; Arantes, V. A review on commercial-scale high-value products that can be produced alongside cellulosic ethanol. Biotechnol. Biofuels 2019, 12, 240. [CrossRef]

49. Padella, M.; O'Connell, A.; Prussi, M. What is still limiting the deployment of cellulosic ethanol? Analysis of the current status of the sector. Appl. Sci. 2019, 9, 4523. [CrossRef]

50. Chowdhary, K.; Prasad, U.; Sharma, S. Role of fungi in biorefinery: A perspective. In Fungal Biorefineries; Kumar, S., Dheeran, P., Taherzadeh, M., Khanal, S., Eds.; Springer: Cham, Switzerland, 2018; pp. 1-20.

51. Chen, M.; Smith, P.M.; Thomchick, E. Qualitative insights into buyer-supplier relationship attributes in the US biofuels industry. Renew. Energy Focus 2017, 22, 1-9. [CrossRef]

52. Janssen, R.; Turhollow, A.F.; Rutz, D.; Mergner, R. Production facilities for second-generation biofuels in the USA and the EU-current status and future perspectives. Biofuel. Bioprod. Biorefin. 2013, 7, 647-665. [CrossRef]

53. Nyström, I.; Bokinge, P.; Franck, P.Å. Production of Liquid Advanced Biofuels-Global Status, CIT Industriell Energi AB. 2019. Available online: https:/ / www.miljodirektoratet.no/globalassets/publikasjoner/m1420/m1420.pdf (accessed on 15 July 2021).

54. Susmozas, A.; Martín-Sampedro, R.; Ibarra, D.; Eugenio, M.E.; Iglesias, R.; Manzanares, P.; Moreno, A.D. Process strategies for the transition of $1 \mathrm{G}$ to advanced bioethanol production. Processes 2020, 8, 1310. [CrossRef]

55. Neto, A.C.; Guimarães, M.J.O.; Freire, E. Business models for commercial scale second-generation bioethanol production. J. Clean Prod. 2018, 184, 168-178. [CrossRef]

56. Shareefdeen, Z.; Elkamel, A.; Tse, S. Review of current technologies used in municipal solid waste-to-energy facilities in Canada. Clean Techn. Environ. Policy 2015, 17, 1837-1846. [CrossRef]

57. Dessie, W.; Luo, X.; Wang, M.; Feng, L.; Liao, Y.; Wang, Z.; Yong, Z.; Qin, Z. Current advances on waste biomass transformation into value-added products. Appl. Microbiol. Biotechnol. 2020, 104, 4757-4770. [CrossRef]

58. Budzianowski, W.M. High-value low-volume bioproducts coupled to bioenergies with potential to enhance business development of sustainable biorefineries. Renew. Sustain. Energy Rev. 2017, 70, 793-804. [CrossRef]

59. Gujer, W.; Zehnder, A.J. Conversion processes in anaerobic digestion. Water Sci. Technol. 1983, 15, 127-167. [CrossRef]

60. Wu, P.; Kang, X.; Wang, W.; Yang, G.; He, L.; Fan, Y.; Cheng, X.; Sun, Y.; Li, L. Assessment of coproduction of ethanol and methane from Pennisetum purpureum: Effects of pretreatment, process performance, and mass balance. ACS Sustain. Chem. Eng. 2021, 9 , 10771-10784.

61. Abomohra, A.E.F.; El-Hefnawy, M.E.; Wang, Q.; Huang, J.; Li, L.; Tang, J.; Mohammed, S. Sequential bioethanol and biogas production coupled with heavy metal removal using dry seaweeds: Towards enhanced economic feasibility. J. Clean. Prod. 2021, 316, 128341. [CrossRef] 
62. Moreno, A.D.; Magdalena, J.A.; Oliva, J.M.; Greses, S.; Lozano, C.C.; Latorre-Sánchez, M.; Negro, M.J.; Susmozas, A.; Iglesias, R.; Llamas, M.; et al. Sequential bioethanol and methane production from municipal solid waste: An integrated biorefinery strategy towards cost-effectiveness. Process. Saf. Environ. Prot. 2021, 146, 424-431. [CrossRef]

63. Rocha-Meneses, L.; Otor, O.F.; Bonturi, N.; Orupõld, K.; Kikas, T. Bioenergy yields from sequential bioethanol and biomethane production: An optimized process flow. Sustainability 2020, 12, 272. [CrossRef]

64. Rocha-Meneses, L.; Raud, M.; Orupõld, K.; Kikas, T. Potential of bioethanol production waste for methane recovery. Energy 2019, 173, 133-139. [CrossRef]

65. Sun, J.; Kosaki, Y.; Watanabe, N.; Ishikawa, M. Production of methane-rich biogas and minimization of sludge by adopting ethanol fermentation for the pretreatment of biomethanation. J. Mater. Cycles Waste Manag. 2019, 21, 258-264. [CrossRef]

66. Rocha-Meneses, L.; Ferreira, J.A.; Bonturi, N.; Orupõld, K.; Kikas, T. Enhancing bioenergy yields from sequential bioethanol and biomethane production by means of solid-liquid separation of the substrates. Energies 2019, 12, 3683. [CrossRef]

67. Kotarska, K.; Dziemianowicz, W.; Świerczyńska, A. Study on the sequential combination of bioethanol and biogas production from corn straw. Molecules 2019, 24, 4558. [CrossRef]

68. Kaur, M.; Kumar, M.; Singh, D.; Sachdeva, S.; Puri, S.K. A sustainable biorefinery approach for efficient conversion of aquatic weeds into bioethanol and biomethane. Energy Convers. Manag. 2019, 187, 133-147. [CrossRef]

69. Fan, M.; Li, J.; Bi, G.; Ye, G.; Zhang, H.; Xie, J. Enhanced co-generation of cellulosic ethanol and methane with the starch/sugar-rich waste mixtures and Tween 80 in fed-batch mode. Biotechnol. Biofuels 2019, 12, 227. [CrossRef]

70. Du, J.; Chen, L.; Li, J.; Zuo, R.; Yang, X.; Chen, H.; Zhuang, X.; Tian, S. High-solids ethanol fermentation with single-stage methane anaerobic digestion for maximizing bioenergy conversion from a C4 grass (Pennisetum purpereum). Appl. Energy. 2018, 215, 437-443. [CrossRef]

71. Elsayed, M.; Abomohra, A.E.F.; Ai, P.; Wang, D.; El-Mashad, H.M.; Zhang, Y. Biorefining of rice straw by sequential fermentation and anaerobic digestion for bioethanol and/or biomethane production: Comparison of structural properties and energy output. Bioresour. Technol. 2018, 268, 183-189. [CrossRef]

72. Calicioglu, O.; Brennan, R.A. Sequential ethanol fermentation and anaerobic digestion increases bioenergy yields from duckweed. Bioresour. Technol. 2018, 257, 344-348. [CrossRef]

73. Zhu, Q.L.; Dai, L.C.; Wu, B.; Tan, F.R.; Wang, W.G.; Tang, X.Y.; Wang, Y.W.; He, M.X.; Hu, G.Q. Integrated methane and ethanol production from livestock manure and soybean straw. Bioresources 2017, 12, 2284-2295. [CrossRef]

74. Katsimpouras, C.; Zacharopoulou, M.; Matsakas, L.; Rova, U.; Christakopoulos, P.; Topakas, E. Sequential high gravity ethanol fermentation and anaerobic digestion of steam explosion and organosolv pretreated corn stover. Bioresour. Technol. 2017, 244, 1129-1136. [CrossRef]

75. Patel, V.R. Cost-effective sequential biogas and bioethanol production from the cotton stem waste. Process. Saf. Environ. 2017, 111, 335-345. [CrossRef]

76. Joelsson, E.; Dienes, D.; Kovacs, K.; Galbe, M.; Wallberg, O. Combined production of biogas and ethanol at high solids loading from wheat straw impregnated with acetic acid: Experimental study and techno-economic evaluation. Sustain. Chem. Process. 2016, 4, 14. [CrossRef]

77. Hashemi, S.S.; Karimi, K.; Nosratpour, M.J.; Sárvári Horváth, I. Efficient biogas and ethanol production from safflower straw using sodium carbonate pretreatment. Energ. Fuels 2016, 30, 10592-10601. [CrossRef]

78. Moshi, A.P.; Temu, S.G.; Nges, I.A.; Malmo, G.; Hosea, K.M.; Elisante, E.; Mattiasson, B. Combined production of bioethanol and biogas from peels of wild cassava Manihot glaziovii. Chem. Eng. J. 2015, 279, 297-306. [CrossRef]

79. Wang, Z.; Lv, Z.; Du, J.; Mo, C.; Yang, X.; Tian, S. Combined process for ethanol fermentation at high-solids loading and biogas digestion from unwashed steam-exploded corn stover. Bioresour. Technol. 2014, 166, 282-287. [CrossRef] [PubMed]

80. Bondesson, P.M.; Galbe, M.; Zacchi, G. Ethanol and biogas production after steam pretreatment of corn stover with or without the addition of sulphuric acid. Biotechnol. Biofuels 2013, 6, 11. [CrossRef]

81. Bahmani, M.A.; Shafiei, M.; Karimi, K. Anaerobic digestion as a pretreatment to enhance ethanol yield from lignocelluloses. Process Biochem. 2016, 51, 1256-1263. [CrossRef]

82. Demichelis, F.; Laghezza, M.; Chiappero, M.; Fiore, S. Technical, economic and environmental assessment of bioethanol biorefinery from waste biomass. J. Clean. Prod. 2020, 277, 124111. [CrossRef]

83. Dererie, D.Y.; Trobro, S.; Momeni, M.H.; Hansson, H.; Blomqvist, J.; Passoth, V.; Schnürer, A.; Sandgren, M.; Ståhlberg, J. Improved bio-energy yields via sequential ethanol fermentation and biogas digestion of steam exploded oat straw. Bioresour. Technol. 2011, 102, 4449-4455. [CrossRef]

84. Papa, G.; Rodriguez, S.; George, A.; Schievano, A.; Orzi, V.; Sale, K.L.; Singh, S.; Adani, F.; Simmons, B.A. Comparison of different pretreatments for the production of bioethanol and biomethane from corn stover and switchgrass. Bioresour. Technol. 2015, 183, 101-110. [CrossRef]

85. Kaparaju, P.; Serrano, M.; Thomsen, A.B.; Kongjan, P.; Angelidaki, I. Bioethanol, biohydrogen and biogas production from wheat straw in a biorefinery concept. Bioresour. Technol. 2009, 100, 2562-2568. [CrossRef]

86. Khoshnevisan, B.; Shafiei, M.; Rajaeifar, M.A.; Tabatabaei, M. Biogas and bioethanol production from pinewood pre-treated with steam explosion and N-methylmorpholine-N-oxide (NMMO): A comparative life cycle assessment approach. Energy 2016, 114, 935-950. [CrossRef] 
87. Shafiei, M.; Karimi, K.; Taherzadeh, M.J. Techno-economical study of ethanol and biogas from spruce wood by NMMOpretreatment and rapid fermentation and digestion. Bioresour. Technol. 2011, 102, 7879-7886. [CrossRef] [PubMed]

88. Bittencourt, G.A.; da Silva Barreto, E.; Brandão, R.L.; Baêta, B.E.L.; Gurgel, L.V.A. Fractionation of sugarcane bagasse using hydrothermal and advanced oxidative pretreatments for bioethanol and biogas production in lignocellulose biorefineries. Bioresour. Technol. 2019, 292, 121963. [CrossRef] [PubMed]

89. da Silva, A.R.G.; Giuliano, A.; Errico, M.; Rong, B.G.; Barletta, D. Economic value and environmental impact analysis of lignocellulosic ethanol production: Assessment of different pretreatment processes. Clean Technol. Environ. Policy 2019, 21, 637-654. [CrossRef]

90. Conde-Mejia, C.; Jimenez-Gutierrez, A.; El-Halwagi, M. A comparison of pretreatment methods for bioethanol production from lignocellulosic materials. Process Saf. Environ. Prot. 2012, 90, 189-202. [CrossRef]

91. Gubicza, K.; Nieves, I.U.; Sagues, W.J.; Barta, Z.; Shanmugam, K.T.; Ingram, L.O. Techno-economic analysis of ethanol production from sugarcane bagasse using a liquefaction plus simultaneous saccharification and co-fermentation process. Bioresour. Technol. 2016, 208, 42-48. [CrossRef] [PubMed]

92. van Rijn, R.; Nieves, I.U.; Shanmugam, K.T.; Ingram, L.O.; Vermerris, W. Techno-economic evaluation of cellulosic ethanol production based on pilot biorefinery data: A case study of sweet sorghum bagasse processed via L+ SScF. BioEnergy Res. 2018, 11, 414-425. [CrossRef]

93. Barrera, I.; Amezcua-Allieri, M.A.; Estupiñan, L.; Martínez, T.; Aburto, J. Technical and economical evaluation of bioethanol production from lignocellulosic residues in Mexico: Case of sugarcane and blue agave bagasses. Chem. Eng. Res. Des. 2016, 107, 91-101. [CrossRef]

94. Quintero, J.A.; Moncada, J.; Cardona, C.A. Techno-economic analysis of bioethanol production from lignocellulosic residues in Colombia: A process simulation approach. Bioresour. Technol. 2013, 139, 300-307. [CrossRef] [PubMed]

95. Hasanly, A.; Talkhoncheh, M.K.; Alavijeh, M.K. Techno-economic assessment of bioethanol production from wheat straw: A case study of Iran. Clean. Technol. Environ. Policy 2018, 20, 357-377. [CrossRef]

96. Li, W.; Ghosh, A.; Bbosa, D.; Brown, R.; Wright, M.M. Comparative techno-economic, uncertainty and life cycle analysis of lignocellulosic biomass solvent liquefaction and sugar fermentation to ethanol. ACS Sustain. Chem. Eng. 2018, 6, 16515-16524. [CrossRef]

97. Boakye-Boaten, N.A.; Kurkalova, L.; Xiu, S.; Shahbazi, A. Techno-economic analysis for the biochemical conversion of Miscanthus $x$ giganteus into bioethanol. Biomass Bioenergy 2017, 98, 85-94. [CrossRef]

98. Da Silva, A.R.G.; Ortega, C.E.T.; Rong, B.G. Techno-economic analysis of different pretreatment processes for lignocellulosic-based bioethanol production. Bioresour. Technol. 2016, 218, 561-570. [CrossRef]

99. Zang, G.; Shah, A.; Wan, C. Techno-economic analysis of an integrated biorefinery strategy based on one-pot biomass fractionation and furfural production. J. Clean. Prod. 2020, 260, 120837. [CrossRef]

100. Hossain, M.S.; Theodoropoulos, C.; Yousuf, A. Techno-economic evaluation of heat integrated second generation bioethanol and furfural coproduction. Biochem. Eng. J. 2019, 144, 89-103. [CrossRef]

101. Bbosa, D.; Mba-Wright, M.; Brown, R.C. More than ethanol: A techno-economic analysis of a corn stover-ethanol biorefinery integrated with a hydrothermal liquefaction process to convert lignin into biochemicals. Biofuel Bioprod. Biorefin. 2018, 12, 497-509. [CrossRef]

102. Kazi, F.K.; Fortman, J.A.; Anex, R.P.; Hsu, D.D.; Aden, A.; Dutta, A.; Kothandaraman, G. Techno-economic comparison of process technologies for biochemical ethanol production from corn stover. Fuel 2010, 89, S20-S28. [CrossRef]

103. Zhao, L.; Zhang, X.; Xu, J.; Ou, X.; Chang, S.; Wu, M. Techno-economic analysis of bioethanol production from lignocellulosic biomass in China: Dilute-acid pretreatment and enzymatic hydrolysis of corn stover. Energies 2015, 8, 4096-4117. [CrossRef]

104. Tao, L.; Aden, A.; Elander, R.T.; Pallapolu, V.R.; Lee, Y.Y.; Garlock, R.J.; Balan, V.; Dale, B.E.; Kim, Y.; Mosier, N.S.; et al. Process and technoeconomic analysis of leading pretreatment technologies for lignocellulosic ethanol production using switchgrass. Bioresour. Technol. 2011, 102, 11105-11114. [CrossRef] [PubMed]

105. Dwivedi, P.; Wang, W.; Hudiburg, T.; Jaiswal, D.; Parton, W.; Long, S.; DeLucia, E.; Khanna, M. Cost of abating Greenhouse Gas emissions with cellulosic ethanol. Environ. Sci. Technol. 2015, 49, 2512-2522. [CrossRef] 